for

\title{
Advanced Oxidation Process with Peracetic Acid and Fe(II)
} for Contaminant Degradation

6

7

8

9

${ }^{1}$ School of Civil and Environmental Engineering, Georgia Institute of Technology, Atlanta, GA Juhee Kim, ${ }^{1}$ Tianqi Zhang, ${ }^{1}$ Wen Liu, ${ }^{1,2}$ Penghui Du, ${ }^{1,3}$ Jordan T. Dobson, ${ }^{1}$ and Ching-Hua Huang*,1 30332, United States

${ }^{2}$ College of Environmental Sciences and Engineering, Peking University, Beijing 100871, China

${ }^{3}$ Beijing Engineering Research Center of Process Pollution Control, Division of Environment Technology and Engineering, Institute of Process Engineering, Chinese Academy of Sciences, Beijing 100190, China

*Corresponding Author. E-mail: ching-hua.huang@,ce.gatech.edu (Ching-Hua Huang) 
Texts

Text S1. Chemicals and reagents, and water sample.

Text S2. Quenched flow system (QFS). ---

Text S3. Analytical methods

Text S4. Toxicity prediction.

Text S5. Linearized second-order kinetic model.

Text S6. Fe(II) regeneration in PAA/Fe(II)/MB system.-----------------------------------S10

Text S7. Proposed reaction products. $\mathrm{S} 10$

\section{Tables}

Table S1. Selected properties of methylene blue (MB), naproxen (NPX), bisphenol-A(BPA), peracetic acid (PAA), and hydrogen peroxide $\left(\mathrm{H}_{2} \mathrm{O}_{2}\right)$----------------S12

Table S2. Thermodynamic properties of PAA and $\mathrm{H}_{2} \mathrm{O}_{2}$. ------------------------------------S13

Table S3. Proposed reaction in Fe(II)/PAA process.----

Table S4. Second-order rate constants $\left(k_{\mathrm{app}}, \mathrm{M}^{-1} \cdot \mathrm{s}^{-1}\right)$ of PAA decomposition by $\mathrm{Fe}(\mathrm{II})$ at initial $\mathrm{pH} 3.0-8.1$ and $22^{\circ} \mathrm{C}\left(\mathrm{R}^{2}>0.99\right)$.

Table S5. Cartesian coordinate of PAA and $\mathrm{H}_{2} \mathrm{O}_{2}$ and their structures. Calculated LUMO values $(\mathrm{B} 3 \mathrm{LYP} / 6-31 \mathrm{G}(\mathrm{d}, \mathrm{p}))$ are $-0.25 \mathrm{eV}$ and $0.57 \mathrm{eV}$, respectively.

Table S6. Extracted spin adduct parameters for several possible radicals in $\mathrm{PAA} / \mathrm{Fe}(\mathrm{II})$ system. Reaction conditions: $[\mathrm{PAA}]_{0}=11.5 \mathrm{mM},[\mathrm{Fe}(\mathrm{II})]=11.5 \mathrm{mM},[\mathrm{TBA}]_{0}=$ $290 \mathrm{mM}$, [DIPPMPO $]_{0}=11 \mathrm{mM}$. -------S16

Table S7. Initial first-order rate constants ( $\left.k_{\text {initial }}\right)$ of degradation of MB, NPX, and BPA by $\mathrm{Fe}(\mathrm{II}) / \mathrm{PAA}$ at initial $\mathrm{pH} 3.0-8.2$ and $22^{\circ} \mathrm{C}\left(\mathrm{R}^{2}>0.93\right)$.

Table S8. Initial first-order rate constants $\left(k_{\text {initial }}\right)$ of degradation of MB by $\mathrm{Fe}(\mathrm{II}) / \mathrm{PAA}$ depending on different molar ratios of PAA to $\mathrm{Fe}(\mathrm{II})$ or $\mathrm{H}_{2} \mathrm{O}_{2}$ at initial $\mathrm{pH} 3.0$ and $22{ }^{\circ} \mathrm{C}\left(\mathrm{R}^{2}>0.95\right)$. S18

Table S9. LC-MS-TOF high resolution accurate mass data. $-S 19$

Table S10. Predicted acute and chronic toxicity of parent compounds and their reaction products by $\mathrm{Fe}(\mathrm{II}) / \mathrm{PAA}$ process using ECOSAR program. S20

\section{Figures}

Figure S1. Quenched flow system (QFS) design: (A) PAA decomposition experiments (B) target compound degradation experiments $(C)$ validation tests.

Figure S2. First-order rate constants obtained in experiments of BPA or triclosan reactivities in chlorine solution containing iodide.

Figure S3. Kinetics of PAA decomposition by different concentrations of $\mathrm{Fe}(\mathrm{II})$ at initial $\mathrm{pH}$ $3.0-8.1$ and $22^{\circ} \mathrm{C}$. S23 
Figure S4. (A) Kinetics of PAA decomposition by $\mathrm{Fe}(\mathrm{II})$ in the presence of different concentrations of $\mathrm{H}_{2} \mathrm{O}_{2}$ at initial $\mathrm{pH} 3.0$ and $22^{\circ} \mathrm{C}\left(\mathrm{R}^{2}>0.98\right)$. (B) Decomposition of PAA and $\mathrm{H}_{2} \mathrm{O}_{2}$ in $\mathrm{Fe}(\mathrm{II}) / \mathrm{PAA}$ system. S24

Figure S5. (A) PAA decomposition by $\mathrm{Fe}(\mathrm{II})$ or $\mathrm{Fe}(\mathrm{III})$. Reaction conditions: [Fe(II) or $\mathrm{Fe}(\mathrm{III})]_{0}=100 \mu \mathrm{M},[\mathrm{PAA}]_{0}=100 \mu \mathrm{M}$, initial $\mathrm{pH} 3.0,22^{\circ} \mathrm{C}$. (B) $\mathrm{H}_{2} \mathrm{O}_{2}$ decomposition by $\mathrm{Fe}(\mathrm{II})$ or $\mathrm{Fe}(\mathrm{III})$. $\mathrm{S} 25$

Figure S6. PAA decomposition by Fe(II) at initial pH 3.0-8.1 with and without TBA addition.-

Figure S7. Degradation of MB, NPX, and BPA by the Fe(II)/PAA process at initial $\mathrm{pH}$ 3.08.2 and $22^{\circ} \mathrm{C}$ with and without TBA addition.

Figure S8. Initial reaction kinetics of (A) MB, (B) NPX, and (C) BPA by Fe(II)/PAA process at initial $\mathrm{pH} 3.0-8.2$ at $22^{\circ} \mathrm{C}$ with and without TBA addition $\left(\mathrm{R}^{2}>0.93\right)$--------S28

Figure S9. Degradation of MB, NPX, and BPA by the Fe(II)/PAA process at initial $\mathrm{pH} 3.0$ 5.0 and $22^{\circ} \mathrm{C}$ with and without $\mathrm{PMSO}$ addition S29

Figure S10. (A) $\mathrm{H}_{2} \mathrm{O}_{2}$ decomposition in $\mathrm{Fe}(\mathrm{II}) / \mathrm{PAA}$ process over time. (B) MB degradation in $\mathrm{Fe}(\mathrm{III}) / \mathrm{H}_{2} \mathrm{O}_{2}$ process over time. S30

Figure S11. Fast degradation of $\mathrm{MB}$ by $\mathrm{Fe}(\mathrm{II}) / \mathrm{PAA}$ process with different molar ratios of (A) PAA : $\mathrm{Fe}(\mathrm{II})$ and (B) PAA : $\mathrm{H}_{2} \mathrm{O}_{2}$. (C) and (D): $\ln \left(\mathrm{C}_{\mathrm{t}} / \mathrm{C}_{0}\right)$ versus time relationships.S31

Figure S12. Change in $\mathrm{Fe}(\mathrm{II})$ concentration in $\mathrm{Fe}(\mathrm{II}) / \mathrm{PAA}$ process $(\mathrm{A})$ over time $\left([\mathrm{Fe}(\mathrm{II})]_{0}=\right.$ $100 \mu \mathrm{M},[\mathrm{PAA}]_{0}=100 \mu \mathrm{M}$, [compound $]_{0}=15 \mu \mathrm{M}$, initial pH 3.0, 22 $\left.{ }^{\circ} \mathrm{C}\right)$; (B) with different $\mathrm{MB}$ concentrations at initial $\mathrm{pH} 3.0$ and $22^{\circ} \mathrm{C}\left([\mathrm{MB}]_{0}=3,6,9\right.$, and 15 $\mu \mathrm{M},[\mathrm{PAA}]_{0}=100 \mu \mathrm{M},[\mathrm{Fe}]_{0}=100 \mu \mathrm{M}$ ). (C) Effects of MB products on determination of $\mathrm{Fe}(\mathrm{II})$ concentration using the ferrozine method. S32

Figure S13. Reaction products of MB (m/z 284.1227) in Fe(II)/PAA process with different reaction times. S33

Figure S14. Reaction products of NPX (m/z 231.1023) in "Fe(II)/PAA" process with different reaction times. S34

Figure S15. Reaction products of BPA (m/z 227.1088) in "Fe(II)/PAA" process with different reaction times. S35 


\section{Text S1. Chemicals, Reagents, and water sample}

PAA solution (39\% PAA and $6 \% \mathrm{H}_{2} \mathrm{O}_{2}$ w/w in acetic acid and water solution), hydrogen peroxide solution $\left(30 \% \mathrm{H}_{2} \mathrm{O}_{2} \mathrm{w} / \mathrm{w}\right.$ in water), ferrous sulfate $\left(\mathrm{FeSO}_{4} \cdot 7 \mathrm{H}_{2} \mathrm{O}\right)$, ferric sulfate $\left(\mathrm{Fe}_{2}\left(\mathrm{SO}_{4}\right)_{3}\right), \mathrm{PMSO}, \mathrm{PMSO}_{2}, \mathrm{DIPPMPO}, \mathrm{MB}, \mathrm{NPX}$ and BPA were purchased from SigmaAldrich (St. Louis, MO, USA) at the highest purity and used without further purification. General properties of PAA, $\mathrm{H}_{2} \mathrm{O}_{2}, \mathrm{MB}, \mathrm{NPX}$ and BPA are listed in the SI Table S1. Other chemicals such as $\mathrm{NaOH}, \mathrm{H}_{2} \mathrm{SO}_{4}, \mathrm{KI}, N, N$-diethyl-p-phenylenediamine (DPD) and others were at reagent-grade and purchased from Sigma-Aldrich (St. Louis, MO, USA) or Fisher Scientific (Fair Lawn, NJ, USA). Reagent-grade deionized (DI) water $(>18 \mathrm{~m} \Omega-\mathrm{cm})$ was generated from a Milli-Q nanopure water purification system (Billerica, MA). Working stock solutions of oxidants (100 mM for PAA, $100 \mathrm{mM}$ for $\left.\mathrm{H}_{2} \mathrm{O}_{2}\right)$, metal salts $(10 \mathrm{mM})$ and target compounds $(1000 \mu \mathrm{M}$ of $\mathrm{MB}, 50 \mu \mathrm{M}$ of NPX, $500 \mu \mathrm{M}$ of BPA) were prepared in DI water immediately prior to each set of experiments. The concentrations of $\mathrm{PAA}$ and $\mathrm{H}_{2} \mathrm{O}_{2}$ in the stock solutions were determined by titration as described previously. ${ }^{1}$

A real wastewater sample was collected on October 15, 2019 from an advanced wastewater treatment plant (WWTP) in the Southeast of the United States. The WWTP employed primary treatment, activated sludge secondary treatment, granular media/membrane filtration, preozonation, biologically-active granular activated carbon (GAC) treatment, and final ozonation. Wastewater sample was collected from the GAC effluent and prior to ozonation, stored at $5^{\circ} \mathrm{C}$ and used within a day. The wastewater $\mathrm{pH}$ was at 6.9 , with UV254 absorbance of 0.066 . 


\section{Text S2. Quenched flow system (QFS)}

Experimental set-up and operation. A quenched flow system (QFS) was designed based on previous work..$^{2,3}$ This system was set up with three Teflon-lined gas-tight glass syringes (Hamilton, Reno, NV, USA) and two syringe pumps (Harvard Apparatus, South Natick, MA, USA, or KD Scientific Inc., Holliston, MA, USA), or with five gas-tight syringes and three pumps as shown in Figure S1. Each syringe contained different experimental stock solution and was connected with a check valve in the tubing to prevent contamination of solution. Before and after each experiment, all syringes and tubes were flushed with methanol, then $0.5 \mathrm{M} \mathrm{H}_{2} \mathrm{SO}_{4}$ in water and finally with DI Water twice. Each pump could be set at flow rates of $1-10 \mathrm{~mL} \cdot \mathrm{min}^{-1}$. For most experiments, the flow rate was 10,10 , and $2 \mathrm{~mL} \cdot \mathrm{min}^{-1}$ for Pumps 1,2 and 3 , respectively. Before each experiment, accurate flow rates were verified. Pump 1 contained two syringes (S1 and S2). Solutions from S1 and S2 were mixed through a mixing tee (T1) (VICI Jour Research, Onsala, Sweden) and the mixed solution flowed through different lengths of loops (PEEK tubing). The mixing tee had a dead volume of $25 \mu \mathrm{L}$ and this dead time was considered in the calculation of accurate reaction time. The lengths of loops were from 4.6 to $275.2 \mathrm{~cm}$, which gave reaction times of $0.14-5.5$ seconds.

For PAA decomposition experiments (Figure S1a), the first syringe contained PAA solution (S1), and the second syringe contained Fe(II) solution (S2), on Pump 1. The 1:1 dilution after mixing S1 and S2 together was taken into account in preparing the experimental stock solutions. The initial $\mathrm{pH}$ of PAA and Fe(II) solutions was adjusted using small drops of $\mathrm{NaOH}(1 \mathrm{M})$ and/or $\mathrm{H}_{2} \mathrm{SO}_{4}(1 \mathrm{M})$ to the desired value. Note that, to prevent the oxidation of $\mathrm{Fe}(\mathrm{II})$ by ambient air, $\mathrm{Fe}(\mathrm{II})$ solution was purged with $\mathrm{N}_{2}$ gas and immediately transferred to the gas-tight syringes after $\mathrm{pH}$ adjustment. S1 and S2 were mixed through the first mixing tee (T1) and flowed through different lengths of loops. This mixture was mixed with KI (S3, $60 \mathrm{mM} \mathrm{KI})$ delivered from Pump 2 through the second mixing tee (T2). Immediately after, this mixture was mixed with 
DPD (S4) and phosphate buffer (S5, 0.5 M at pH 6.5) delivered from Pump 3 through the third mixing tee (T3). The use of excess of KI quenched the reaction of PAA with $\mathrm{Fe}(\mathrm{II})\left(k_{\mathrm{PAA}, \mathrm{KI}} \times\right.$ $\left.[\mathrm{KI}]>k_{\mathrm{PAA}, \mathrm{Fe}(\mathrm{II})} \times[\mathrm{Fe}(\mathrm{II})]\right)$. The molar ratio of DPD to PAA was kept at 7.2 or greater to ensure the complete quantification of PAA. The quenched mixture was analyzed by UV-vis spectrophotometry at $515 \mathrm{~nm}$ after exactly 60 seconds of pink color development.

For $\mathrm{H}_{2} \mathrm{O}_{2}$ decomposition experiments (Figure $\mathrm{S} 1 b$ ), after $\mathrm{H}_{2} \mathrm{O}_{2}$ solution (S1) and $\mathrm{Fe}(\mathrm{II})$ solution (S2) were mixed and flowed through the different loops, the mixture was mixed with $\mathrm{Ti}_{2}\left(\mathrm{SO}_{4}\right)_{3}$ (S3) to quench $\mathrm{H}_{2} \mathrm{O}_{2}$. This quenched mixture was analyzed by UV-vis spectrophotometry at $405 \mathrm{~nm}$ after exactly 60 seconds of yellow color development.

For target compound degradation experiments (Figure S1b), the first syringe contained solution of target compound and PAA (S1), and the second syringe contained Fe(II) solution (S2). The third syringe contained the quencher solution ( $\left.\mathrm{S} 3,10 \mathrm{mM} \mathrm{Na} 2 \mathrm{~S}_{2} \mathrm{O}_{3}\right) . \mathrm{S} 1$ and $\mathrm{S} 2$ were mixed through the first mixing tee (T1) and the mixture flowed through different lengths of loops. Then, the mixture was mixed with $\mathrm{Na}_{2} \mathrm{~S}_{2} \mathrm{O}_{3}(\mathrm{~S} 3)$ delivered from Pump 2 through the second mixing tee (T2). This quenched mixture was analyzed by UV-vis spectrophotometry for MB, or collected for further analysis by HPLC or LC/MS.

Validation of QFS. Experiments were conducted to verify the accuracy of the QFS by comparing results with the reported kinetic rate constants ${ }^{2}$ for the reactivities of BPA and triclosan in aqueous chlorine solution containing iodide. The experimental procedures and conditions were similar to those in the previous work. ${ }^{2}$ Firstly, three times greater concentrations of iodide, chlorine, and phenolic compound solutions were prepared to obtain a desired concentration after a 1:3 dilution, and each solution's $\mathrm{pH}$ was set at $\mathrm{pH} 7.5$ or 9.0 using sodium bicarbonate buffer. As shown in Figure S1c, iodide solution (S1, KI) and chlorine solution (S2, $\mathrm{NaOCl}$ ) were first mixed at $\mathrm{T} 1$ by Pump 1 . Then, this mixture was mixed with phenolic compound solution (S3, BPA or triclosan) delivered by Pump 2 through the mixing tee T2 and 
flowed through different lengths of loops. Finally, this reaction mixture was mixed with DPD (S4) and phosphate buffer (S5) delivered by Pump 3. The quenched mixture was analyzed by UV-vis spectrophotometry at $515 \mathrm{~nm}$ after exactly 60 seconds of pink color development. As shown in Figure S2, results (i.e. $k_{\text {initial }}$ in $\mathrm{s}^{-1}$ ) obtained from the QFS in this study agreed very well with the values reported from the previous study, confirming the accuracy of the QFS setup.

\section{Text S3. Analytical methods}

Reactants. Concentrations of MB, NPX, BPA, $\mathrm{PMSO}$, and $\mathrm{PMSO}_{2}$ were analyzed using an Agilent 1100 HPLC/diode-array detector (DAD) system equipped with an Agilent Zorbax Eclipse XDB-C8 column $(4.6 \times 150 \mathrm{~mm}, 5 \mu \mathrm{m})(\mathrm{MB})$ or Zorbax SB-C18 column $(2.1 \times 150$ mm, $5 \mu \mathrm{m}$ ) (NPX, BPA, PMSO and $\mathrm{PMSO}_{2}$ ). The isocratic mobile phase was: (i) 40/60 (v/v) of acetonitrile/0.1 M ammonium acetate and $0.1 \mathrm{M}$ acetic acid in water for $\mathrm{MB}$ at $0.25 \mathrm{~mL} \cdot \mathrm{min}^{-1}$; or (ii) 40/60 (v/v) of acetonitrile/0.1 \% (v/v) formic acid in water for NPX and BPA at 0.4$\mathrm{mL} \cdot \mathrm{min}^{-1}$, or (iii) $20 / 80(\mathrm{v} / \mathrm{v})$ of acetonitrile/0.1 \% (v/v) formic acid in water for PMSO and $\mathrm{PMSO}_{2}$ at $0.25-\mathrm{mL} \cdot \mathrm{min}^{-1}$. Wavelengths of DAD were set at 290 (or 652), 230, 201, 230, and $215 \mathrm{~nm}$ for $\mathrm{MB}, \mathrm{NPX}, \mathrm{BPA}, \mathrm{PMSO}$, and $\mathrm{PMSO}_{2}$, respectively. Ferrous ion concentration in samples was determined by the ferrozine method at $562 \mathrm{~nm}$ or 1,10-phenanthroline method at $510 \mathrm{~nm}^{4,5}$

Reaction Products. To identify initial reaction products, $100 \mathrm{~mL}$ of sample was collected from QFS using designated loops for each reaction time $(0.14-1.12 \mathrm{sec})$ from multiple experiments if needed, and several samples were prepared from batch reactor at each reaction time (10 sec-2 $\mathrm{min})$. Then, samples were subjected to solid phase extraction (SPE). SPE cartridges (OASIS HLB, Waters, Milford, MC) were preconditioned with $5 \mathrm{~mL} \mathrm{MeOH}$ and 5 mL DI water. After samples were loaded, SPE cartridges were rinsed with $10 \mathrm{~mL}$ DI water and 
eluted with $8 \mathrm{~mL} \mathrm{MeOH}$. The extracted sample was concentrated to $3 \mathrm{~mL}$ in volume using a concentrator (CentriVap, Labconco, USA) and transferred to amber vials. An Agilent 1260 Infinity HPLC with 6230 time-of-flight mass spectrometry system was used to analyze the products under electrospray ionization (ESI+ for MB and NAP; ESI- for BPA) in full scan mode (m/z 100-900). Compounds were separated using a Poroshell 120 EC-C18 column $(2.1 \times 150$ mm, $2.7 \mu \mathrm{m}$ ) with $40 \mu \mathrm{L}$ injection volume. The mobile phase was: (A) $0.1 \%(\mathrm{v} / \mathrm{v})$ formic acid in water and (B) acetonitrile for ESI+; or (A) $0.1 \%$ acetic acid and $0.1 \%(\mathrm{v} / \mathrm{v})$ ammonium acetate and (B) 50/50 (v/v) methanol/acetonitrile for ESI-, at a flow rate of $0.3 \mathrm{~mL} \cdot \mathrm{min}^{-1}$ with gradient elution. The drying gas flow rate was $7 \mathrm{~L} \cdot \mathrm{min}^{-1}$, gas temperature $350{ }^{\circ} \mathrm{C}$, nebulizer pressure 40 psi, capillary voltage $3500 \mathrm{~V}$, and fragmentation voltage 140, 180, 220, and $250 \mathrm{~V}$. Data acquisition and data processing were conducted with errors between the calculated and measured mass less than $\pm 10 \mathrm{ppm}$, providing confident empirical formula of the reaction products.

Electron paramagnetic resonance (EPR). Aqueous solutions of PAA, Fe(II), and DIPPMPO (5-diisopropoxyphosphoryl-5-methyl-1-pyrroline N-oxide) were mixed, plus with or without TBA solution, into a capillary tube, which was immediately inserted into the cavity of the EPR spectrometer (Bruker, Germany). Instrument settings were $10 \mathrm{~mW}$ microwave power, $100 \mathrm{kHz}$ modulation frequency, $1 \mathrm{G}$ modulation amplitude, $3510 \mathrm{G}$ center filed, and $200 \mathrm{G}$ seep width. Identification of radicals was conducted with the assistance of the Easyspin software (version 5.2.25 toolbox for MATLAB (The MathWorks, INC., USA)). The splitting pattern for a DIPPMPO radical adduct was derived from one $\mathrm{N}$, one $\mathrm{H}$, and one $\mathrm{P}$. Fitted parameters from the best fit of the experimental adduct spectra were hyperfine coupling constants $\left(\alpha_{H}, G, \alpha_{N}, G, \alpha_{P}, G\right)$ and the ratio of amounts of each component in the adducts spectra. Table S6 shows the results.

\section{Text S4. Toxicity prediction}


216 Toxicity of target compounds and their reaction products was predicted using the USEPA 217 ECOSAR v2.0 software. ${ }^{6}$ The ECOSAR relies on quantitative structure-activity relationships

(QSARs) to predict the aquatic toxicity on the basis of structure similarity of a given compound with known toxicity values of other compounds. This software evaluates exposure risks to green algae, daphnid, and fish. In this study, the acute toxicity ( $\mathrm{LC}_{50}$ and $\left.\mathrm{EC}_{50}\right)$ and chronic toxicity $(\mathrm{ChV})$ were estimated and classified according to the Globally Harmonized System of Classification and Labelling of Chemicals. ${ }^{7}$

\section{Text S5. Linearized second-order kinetic model}

The apparent second-order rate constants $\left(k_{\text {app }}\right)$ were determined by applying equation $(\mathrm{S} 1)^{5}$ to the measured PAA and $\mathrm{Fe}(\mathrm{II})$ concentrations over time in experiments:

$$
\frac{1}{\left([\mathrm{Fe}(\mathrm{II})]_{0}-[\mathrm{PAA}]_{0}\right)} \ln \left(\frac{[\mathrm{PAA}]_{0}[\mathrm{Fe}(\mathrm{II})]}{[\mathrm{Fe}(\mathrm{II})]_{0}[\mathrm{PAA}]}\right)=k \cdot \mathrm{t} \text { when }[\mathrm{PAA}]_{0} \neq[\mathrm{Fe}(\mathrm{II})]_{0}
$$

Here, $[\mathrm{Fe}(\mathrm{II})]_{0}$ and $[\mathrm{PAA}]_{0}$ are concentrations (in $\mathrm{M}$ ) at $\mathrm{t}=0,[\mathrm{Fe}(\mathrm{II})]$ and $[\mathrm{PAA}]$ are concentrations (in $\mathrm{M}$ ) at $\mathrm{t}=\mathrm{t}$, and $k$ is $k_{\text {app }}\left(\right.$ in $\left.\mathrm{M}^{-1} \mathrm{~s}^{-1}\right)$. It was assumed $[\mathrm{Fe}(\mathrm{II})] \approx[\mathrm{Fe}(\mathrm{II})]_{0}-$ ([PAA $\left.]_{0}-[\mathrm{PAA}]\right)$ for 1:1 stoichiometry, and this assumption was confirmed by the experimental data. The plot of the left-hand side of equation (S1) vs time appeared linear, and linear regression was used to obtain the value of $k\left(\mathrm{R}^{2}>0.99\right)$.

\section{Text S6. Fe(II) regeneration in $\mathrm{PAA} / \mathrm{Fe}(\mathrm{II}) / \mathrm{MB}$ system}

A re-increase in $\mathrm{Fe}(\mathrm{II})$ concentration in the second reaction stage was observed with $\mathrm{MB}$ (Figure S12A). One possible explanation is the reaction of $\mathrm{Fe}(\mathrm{III})$ and/or $\mathrm{Fe}(\mathrm{IV})$ with some reducing agents (e.g., reaction products of $\mathrm{MB}$ ) generated during the reaction. To evaluate the effect of reaction products, $\mathrm{Fe}(\mathrm{II})$ concentration was determined in $\mathrm{Fe}(\mathrm{II}) / \mathrm{PAA}$ process with different $\mathrm{MB}$ concentrations (from 3 to $15 \mu \mathrm{M}$ ). Figure S12B shows that $\mathrm{Fe}$ (II) concentration 
increased with increasing MB concentration. Moreover, the increase of Fe(II) concentration with reaction time was enhanced when a higher concentration of MB was added. These results confirmed that reaction products of MB could react with $\mathrm{Fe}(\mathrm{III})$ and/or $\mathrm{Fe}(\mathrm{IV})$ to generate $\mathrm{Fe}(\mathrm{II})$. Separate experiments verified that $\mathrm{MB}$ reaction products did not interfere with $\mathrm{Fe}(\mathrm{II})$ measurement by the ferrozine method (Figure S12C).

\section{Text S7. Proposed reaction products and formation}

For all three compounds, prominent formation of hydroxylated products $(+\mathrm{m} / \mathrm{z} 16)$ was observed initially. It is proposed that the formation of products was initiated by electron transfer from MB, NPX, and NPA to $\mathrm{CH}_{3} \mathrm{C}(\mathrm{O}) \mathrm{O}^{\bullet}$ and/or $\mathrm{CH}_{3} \mathrm{C}(\mathrm{O}) \mathrm{OO}^{*}$. Then, the radical cations $\left(\mathrm{MB}^{\cdot+}, \mathrm{NPX}^{\cdot+}\right.$, and $\mathrm{BPA}^{\bullet+}$ ) could rapidly react with $\mathrm{H}_{2} \mathrm{O}$ or $\mathrm{O}_{2}$ via hydroxyl abstraction or addition reaction to generate hydroxylated products (i.e. m/z 332.1051/300.1183, 247.0971 and 243.1033 products for MB, NPX, and NPA, respectively). The electrophilic attack of carbon-centered radicals preferred the aromatic ring due to higher electron density, similar to the behavior of $\mathrm{SO}_{4}{ }^{\circ}$. Similar to previous work, ${ }^{1}$ products with addition of $\mathrm{CH}_{3} \mathrm{C}(\mathrm{O}) \mathrm{O}^{\bullet}$ or $\mathrm{CH}_{3} \mathrm{C}(\mathrm{O}) \mathrm{OO}{ }^{\bullet}$ to the parent compounds were not observed. In general, the reaction of electron transfer to radicals is fast for many compounds; ${ }^{6}$ however, experimental investigation of electron transfer pathway for $\mathrm{CH}_{3} \mathrm{C}(\mathrm{O}) \mathrm{O}^{\bullet}$ or $\mathrm{CH}_{3} \mathrm{C}(\mathrm{O}) \mathrm{OO}^{\bullet}$ is limited in literature. Several studies can support the electron transfer reaction between compounds and $\mathrm{CH}_{3} \mathrm{C}(\mathrm{O}) \mathrm{O}^{\bullet}$ or $\mathrm{CH}_{3} \mathrm{C}(\mathrm{O}) \mathrm{OO}{ }^{*}$. Schuchmann et al. ${ }^{7}$ reported the fast electron transfer rates of $\mathrm{CH}_{3} \mathrm{C}(\mathrm{O}) \mathrm{OO}{ }^{\circ}$ with ascorbate ion, $N, N, N^{\prime}, N^{\prime}-$ tetramethyl-p-phenylenediamine, and 2,2-azinobis(3-ethylbenzthiazoline-6-phosphate) $\left(k=8.3 \times 10^{8}-1.9 \times 10^{9} \mathrm{M}^{-1} \cdot \mathrm{s}^{-1}\right)$. Bietti et al. ${ }^{8}$ also provided clear evidence for an electron transfer between alkoxyl radicals (tert-butoxyl, cumyloxyl, and benzyloxyl) and alkyl ferrocenes $\left(k=9.6 \times 10^{6}-1.1 \times 10^{10} \mathrm{M}^{-1} \cdot \mathrm{s}^{-1}\right)$. Moreover, the detection of products similar to the ones generated by $\mathrm{SO}_{4}^{--}$oxidation $^{9,10}$ also supported that the electron transfer between compounds and 
$265 \mathrm{CH}_{3} \mathrm{C}(\mathrm{O}) \mathrm{O}^{\bullet}$ or $\mathrm{CH}_{3} \mathrm{C}(\mathrm{O}) \mathrm{OO}^{*}$ could be a key mechanism triggering subsequent products 266 formation. Literature regarding Fe(IV) oxidation reactions is still limited. However, the initial 267 hydroxylated products ( $+\mathrm{m} / \mathrm{z}$ 16) could be also related to the electron transfer reaction by Fe(IV). 268 Feng et al. ${ }^{11}$ suggested that Fe(IV) was involved in the generation of hydroxylated products of 269 sulfadimethoxine. Although Fe(IV) is a selective oxidant, reaction mechanisms and reaction 270 products are often similar to those by radicals, rendering difficulty to identify $\mathrm{Fe}(\mathrm{IV})$ versus 271 radicals. ${ }^{12}$ Jacobsen et al. ${ }^{13}$ suggested that the reaction mechanism of Fe(IV) with organic 272 compounds was similar to the ${ }^{\circ} \mathrm{OH}$ at acidic condition (i.e., $\mathrm{H}$-abstraction). 
Table S1. Selected properties of methylene blue (MB), naproxen (NPX), bisphenol-A(BPA), peracetic acid (PAA), and hydrogen peroxide ( $\left.\mathrm{H}_{2} \mathrm{O}_{2}\right)$.

\begin{tabular}{|c|c|c|c|c|c|}
\hline \multirow{2}{*}{ Properties } & \multicolumn{3}{|c|}{ Compounds } & \multicolumn{2}{|c|}{ Oxidants } \\
\hline & $\mathbf{M B}^{\mathbf{a}}$ & NPX & BPA & PAA & $\mathbf{H}_{2} \mathbf{O}_{2}$ \\
\hline Chemical formula & $\mathrm{C}_{16} \mathrm{H}_{18} \mathrm{ClN}_{3} \mathrm{~S}$ & $\mathrm{C}_{14} \mathrm{H}_{14} \mathrm{O}_{3}$ & $\mathrm{C}_{15} \mathrm{H}_{16} \mathrm{O}_{2}$ & $\mathrm{CH}_{3} \mathrm{CO}_{3} \mathrm{H}$ & $\mathrm{H}_{2} \mathrm{O}_{2}$ \\
\hline Molecular structure & & & & & \\
\hline Molecule weight $\left(\mathrm{g} \mathrm{mol}^{-1}\right)$ & 319.85 & 230.26 & 228.29 & 76.05 & 34.01 \\
\hline $\mathrm{p} K_{\mathrm{a}}\left(25^{\circ} \mathrm{C}\right)$ & $<1.0$ & 4.2 & 9.2 & 8.20 & 11.75 \\
\hline $\log K_{\text {ow }}$ & 2.35 & 3.2 & 3.4 & -1.07 & -1.5 \\
\hline Solubility in water $\left(\mathrm{mg} \mathrm{L}^{-1}, 25^{\circ} \mathrm{C}\right)$ & $3.6 \times 10^{6}$ & $1.59 \times 10^{1}$ & $1.20 \times 10^{2}$ & miscible & miscible \\
\hline
\end{tabular}


Table S2. Thermodynamic properties of PAA and $\mathrm{H}_{2} \mathrm{O}_{2}$

\begin{tabular}{l|l|l}
\hline Properties & PAA & $\mathbf{H}_{\mathbf{2}} \mathbf{O}_{2}$ \\
\hline$\triangle \mathrm{G}_{f}^{0}\left(\mathrm{~kJ} \cdot \mathrm{mol}^{-1}\right)$, at $273.15 \mathrm{~K}$ & -299.41 & -138.49 \\
\hline Standard reduction potential $(\mathrm{V})$ & $1.96 \mathrm{~V}^{14,15}$ & $1.763 \mathrm{~V}(\mathrm{pH} \mathrm{0})^{16}$ \\
& $1.748 \mathrm{~V}(\mathrm{pH} \mathrm{0})^{14,15}$ & $0.878 \mathrm{~V}(\mathrm{pH} \mathrm{14})^{16}$ \\
& $1.005 \mathrm{~V}(\mathrm{pH} \mathrm{14})^{14,15}$ & \\
\hline O-OH bond energy $\left(\mathrm{kcal} \cdot \mathrm{mol}^{-1}\right)$ & $38^{17}$ & $51^{17}$ \\
\hline OO-H bond energy $\left(\mathrm{kcal} \cdot \mathrm{mol}^{-1}\right)$ & $88.4-94.8^{18}$ & $90^{19}$ \\
\hline LUMO energy $(\mathrm{eV})$ & -0.25 & 0.57 \\
\hline
\end{tabular}

Table S3. Proposed reactions in Fe(II)/PAA process

\begin{tabular}{|c|c|c|c|}
\hline No. & Proposed reaction in $\mathrm{Fe}(\mathrm{II}) / \mathrm{PAA}$ process & $k\left(\mathbf{M}^{-1} \mathbf{s}^{-1}\right)$ & References \\
\hline$(1)$ & $\mathrm{CH}_{3} \mathrm{C}(\mathrm{O}) \mathrm{OOH}+\mathrm{Fe}^{2+} \rightarrow \mathrm{CH}_{3} \mathrm{C}(\mathrm{O}) \mathrm{O}^{\cdot}+\mathrm{Fe}^{3+}+\mathrm{OH}^{-}$ & \multirow{3}{*}{$(0.16-1.10) \times 10^{5}$} & \multirow{3}{*}{ This study } \\
\hline$(2)$ & $\mathrm{CH}_{3} \mathrm{C}(\mathrm{O}) \mathrm{OOH}+\mathrm{Fe}^{2+} \rightarrow \mathrm{CH}_{3} \mathrm{C}(\mathrm{O}) \mathrm{O}^{-}+\mathrm{Fe}^{3+}+{ }^{\cdot} \mathrm{OH}$ & & \\
\hline (3) & $\mathrm{CH}_{3} \mathrm{C}(\mathrm{O}) \mathrm{OOH}+\mathrm{Fe}^{2+} \rightarrow \mathrm{CH}_{3} \mathrm{C}(\mathrm{O}) \mathrm{OH}+\mathrm{Fe}^{\mathrm{IV}} \mathrm{O}^{2+}$ & & \\
\hline (4) & $\mathrm{H}_{2} \mathrm{O}_{2}+\mathrm{Fe}^{2+} \rightarrow{ }^{\cdot} \mathrm{OH}+\mathrm{Fe}^{3+}+\mathrm{OH}^{-}$ & \multirow[t]{2}{*}{$63-76$} & 20 \\
\hline$(5)$ & $\mathrm{H}_{2} \mathrm{O}_{2}+\mathrm{Fe}^{2+} \rightarrow \mathrm{H}_{2} \mathrm{O}+\mathrm{Fe}^{\mathrm{IV}} \mathrm{O}^{2+}$ & & 21 \\
\hline$(6)$ & $\mathrm{H}_{2} \mathrm{O}_{2}+\mathrm{Fe}^{3+} \rightarrow \mathrm{HO}_{2}{ }^{-}+\mathrm{Fe}^{2+}+\mathrm{H}^{+}$ & $0.001-0.01$ & $22-24$ \\
\hline$(7)$ & $\mathrm{CH}_{3} \mathrm{C}(\mathrm{O}) \mathrm{OOH}+\mathrm{Fe}^{3+} \rightarrow \mathrm{CH}_{3} \mathrm{C}(\mathrm{O}) \mathrm{OO}^{\bullet}+\mathrm{Fe}^{2+}+\mathrm{H}^{+}$ & 2.72 & This study \\
\hline$(8)$ & $\mathrm{CH}_{3} \mathrm{C}(\mathrm{O}) \mathrm{OOH}+\mathrm{CH}_{3} \mathrm{C}(\mathrm{O}) \mathrm{O}^{*} \rightarrow \mathrm{CH}_{3} \mathrm{C}(\mathrm{O}) \mathrm{OO}^{*}+\mathrm{CH}_{3} \mathrm{C}(\mathrm{O}) \mathrm{OH}$ & & 1,25 \\
\hline (9) & $\mathrm{H}_{2} \mathrm{O}_{2}+\mathrm{CH}_{3} \mathrm{C}(\mathrm{O}) \mathrm{O}^{\cdot} \rightarrow \mathrm{HO}_{2}^{\cdot}+\mathrm{CH}_{3} \mathrm{C}(\mathrm{O}) \mathrm{OH}$ & & \\
\hline$(10)$ & $\mathrm{CH}_{3} \mathrm{C}(\mathrm{O}) \mathrm{OOH}+{ }^{\cdot} \mathrm{OH} \rightarrow \mathrm{CH}_{3} \mathrm{C}(\mathrm{O}) \mathrm{OO}^{\bullet}+\mathrm{H}_{2} \mathrm{O}$ & \multirow[t]{3}{*}{$9.33 \times 10^{8}$} & 1 \\
\hline$(11)$ & $\mathrm{CH}_{3} \mathrm{C}(\mathrm{O}) \mathrm{OOH}+{ }^{\circ} \mathrm{OH} \rightarrow \mathrm{CH}_{3} \mathrm{C}(\mathrm{O})^{\cdot}+\mathrm{H}_{2} \mathrm{O}+\mathrm{O}_{2}$ & & 1,25 \\
\hline$(12)$ & $\mathrm{CH}_{3} \mathrm{C}(\mathrm{O}) \mathrm{OOH}+{ }^{\circ} \mathrm{OH} \rightarrow \mathrm{CH}_{3} \mathrm{C}(\mathrm{O}) \mathrm{OH}+\mathrm{HO}_{2}^{\cdot}$ & & 1 \\
\hline$(13)$ & $\mathrm{H}_{2} \mathrm{O}_{2}+{ }^{\circ} \mathrm{OH} \rightarrow \mathrm{HO}_{2}^{\cdot}+\mathrm{H}_{2} \mathrm{O}$ & $3.3 \times 10^{7}$ & $20,25,26$ \\
\hline$(14)$ & $\mathrm{H}_{2} \mathrm{O}_{2}+2 \mathrm{Fe}^{\mathrm{IV}} \mathrm{O}^{2+} \rightarrow \mathrm{HO}_{2}^{\cdot}+\mathrm{Fe}^{3+}+\mathrm{OH}^{-}$ & $1 \times 10^{4}$ & 13,27 \\
\hline$(15)$ & $\mathrm{CH}_{3} \mathrm{C}(\mathrm{O}) \mathrm{OOH}+2 \mathrm{Fe}^{\mathrm{IV}} \mathrm{O}^{2+} \rightarrow \mathrm{CH}_{3} \mathrm{C}(\mathrm{O}) \mathrm{O}^{-}+2 \mathrm{Fe}^{3+}+\mathrm{OH}^{-}+\mathrm{O}_{2}$ & & \\
\hline$(16)$ & $\mathrm{Fe}^{\mathrm{IV}} \mathrm{O}^{2+}+\mathrm{H}_{2} \mathrm{O} \rightarrow{ }^{\circ} \mathrm{OH}+\mathrm{Fe}^{3+}+\mathrm{OH}^{-}$ & $0.013 \mathrm{~s}^{-1}$ & 27 \\
\hline$(17)$ & $\mathrm{CH}_{3} \mathrm{C}(\mathrm{O}) \mathrm{O}^{\cdot} \rightarrow{ }^{\circ} \mathrm{CH}_{3}+\mathrm{CO}_{2}$ & $1 \times 10^{5} \mathrm{~s}^{-1}$ & $1,25,28$ \\
\hline$(18)$ & ${ }^{\circ} \mathrm{CH}_{3}+\mathrm{O}_{2} \rightarrow \mathrm{CH}_{3} \mathrm{OO} \cdot$ & $(2.8-4.1) \times 10^{9}$ & $1,25,29$ \\
\hline
\end{tabular}


Table S4. Second-order rate constants $\left(k_{\mathrm{app}}, \mathrm{M}^{-1} \cdot \mathrm{s}^{-1}\right)$ of PAA decomposition by $\mathrm{Fe}(\mathrm{II})$ at initial $\mathrm{pH} 3.0-8.1$ and $22^{\circ} \mathrm{C}\left(\mathrm{R}^{2}>0.99\right)$. Reaction condition: $[\mathrm{PAA}]_{0}=20 \mu \mathrm{M},[\mathrm{Fe}(\mathrm{II})]_{0}=5 \mu \mathrm{M}$.

\begin{tabular}{cc}
\hline $\mathbf{p H}$ & $\boldsymbol{k}_{\text {app }}, \mathbf{M}^{-\mathbf{1}} \cdot \mathbf{s}^{-\mathbf{1}}$ \\
\hline 3.0 & $1.10 \pm 0.02 \times 10^{5}$ \\
4.0 & $1.01 \pm 0.02 \times 10^{5}$ \\
5.0 & $8.60 \pm 0.03 \times 10^{4}$ \\
6.0 & $6.69 \pm 0.01 \times 10^{4}$ \\
7.1 & $5.01 \pm 0.01 \times 10^{4}$ \\
8.2 & $1.56 \pm 0.01 \times 10^{4}$ \\
\hline
\end{tabular}

Rate constants obtained from linear regression of all data points of replicate experiments and reported with standard error.

The stoichiometry between Fe(II) and PAA was 1:1.04, which agreed well with the expected 1:1. 
Table S5. Cartesian coordinate of PAA and $\mathrm{H}_{2} \mathrm{O}_{2}$ and their structures. Calculated LUMO values $(\mathrm{B} 3 \mathrm{LYP} / 6-31 \mathrm{G}(\mathrm{d}, \mathrm{p}))$ are $-0.25 \mathrm{eV}$ and $0.57 \mathrm{eV}$, respectively. Calculations were performed using Gaussian 03 software. $^{8}$

\begin{tabular}{ccccc}
\hline & Symbol & \multicolumn{1}{c}{$\mathbf{X}$} & \multicolumn{1}{c}{$\mathbf{Y}$} & $\mathbf{Z}$ \\
\hline & $\mathrm{C}$ & 0.54057856 & 1.37394939 & 0.01169623 \\
$\mathrm{H}$ & 0.03176003 & 1.74544121 & -0.88171739 \\
& $\mathrm{H}$ & 1.56417851 & 1.74491961 & 0.04430881 \\
& $\mathrm{H}$ & -0.02472363 & 1.73463688 & 0.87428737 \\
& $\mathrm{C}$ & 0.59548827 & -0.12919819 & 0.00288319 \\
& $\mathrm{O}$ & 1.58693227 & -0.81229707 & 0.01021741 \\
& $\mathrm{O}$ & -0.60024544 & -0.81623390 & -0.02695953 \\
& $\mathrm{O}$ & -1.74307185 & 0.09234617 & -0.06418066 \\
& $\mathrm{H}$ & -2.33653577 & -0.40402641 & 0.52302698 \\
\hline & $\mathrm{Symbol}$ & $\mathbf{X}$ & $\mathbf{Y}$ & $\mathbf{Z}$ \\
\hline & $\mathrm{O}$ & 0.00000000 & 0.73320938 & -0.00023166 \\
& $\mathrm{H}$ & 0.95945604 & 0.87228568 & 0.00185331 \\
& $\mathrm{O}$ & -0.00000000 & -0.73320938 & -0.00023166 \\
& $\mathrm{H}$ & -0.95945604 & -0.87228568 & 0.00185331 \\
\hline
\end{tabular}


Table S6. Extracted spin adduct parameters for several possible radicals in PAA/Fe(II) system. Reaction conditions: [PAA $]_{0}=11.5 \mathrm{mM},[\mathrm{Fe}(\mathrm{II})]$ $=11.5 \mathrm{mM},[\mathrm{TBA}]_{0}=290 \mathrm{mM},[\mathrm{DIPPMPO}]_{0}=11 \mathrm{mM}$. The simulation-based fitting revealed the presence of ${ }^{\circ} \mathrm{OH}\left(\alpha_{\mathrm{H}}=13.7, \alpha_{\mathrm{N}}=10.3, \alpha_{\mathrm{P}}=\right.$ $50.9), \mathrm{CH}_{3} \mathrm{C}(\mathrm{O})^{\circ}\left(\alpha_{\mathrm{H}}=21.2, \alpha_{\mathrm{N}}=14.5, \alpha_{\mathrm{P}}=48.9\right)$, and ${ }^{\circ} \mathrm{CH}_{3}\left(\alpha_{\mathrm{H}}=22.8, \alpha_{\mathrm{N}}=15.1, \alpha_{\mathrm{P}}=45.5\right)$. These extracted hyperfine splitting constants $(\alpha \mathrm{H}$, $\left.\alpha_{\mathrm{N}}, \alpha_{\mathrm{P}}\right)$ corresponded very well with values reported in other studies. ${ }^{25,30-32}$

\begin{tabular}{|c|c|c|c|c|c|c|c|c|}
\hline \multirow[b]{2}{*}{ Radicals } & \multicolumn{2}{|c|}{ Weight $^{a}$} & \multicolumn{2}{|c|}{$\alpha_{\mathrm{H}, \mathrm{G}}$} & \multicolumn{2}{|c|}{$\alpha_{N}, G$} & \multicolumn{2}{|c|}{$\alpha_{P}, \mathrm{G}$} \\
\hline & $\mathrm{W} / \mathrm{O}$ TBA & W/ TBA & This study & ${ }_{32} \operatorname{Reference}^{25,30-}$ & This study & Reference & This study & Reference \\
\hline $\mathrm{CH}_{3} \mathrm{C}(\mathrm{O}) \mathrm{O} \bullet$ & 0.44 & 0.06 & 13.7 & 13.9 & 10.3 & 10.2 & 50.9 & 50.9 \\
\hline $\mathrm{CH}_{3} \mathrm{CO} \bullet$ & 0.36 & 0.13 & 21.2 & $21.2,22.2$ & 14.5 & $14.2,14.8$ & 48.9 & $49.0,49.5$ \\
\hline$\cdot \mathrm{CH}_{3}$ & 0.05 & 0.96 & 22.8 & $22.3,22.6$ & 15.1 & $14.4,14.8$ & 45.5 & $47.1,47.1$ \\
\hline
\end{tabular}

${ }^{a}$ This field weight is used as prefactors when the total spectrum is constructed as a weighted sum of each component spectra. 
Table S7. Initial first-order rate constants $\left(k_{\text {initial }}\right)$ of degradation of MB, NPX, and BPA by Fe(II)/PAA at initial $\mathrm{pH} 3.0-8.2$ and $22^{\circ} \mathrm{C}\left(\mathrm{R}^{2}>0.93\right)$. Reaction conditions: $[\mathrm{PAA}]_{0}$ and $[\mathrm{Fe}(\mathrm{II})]_{0}=100 \mu \mathrm{M}$, and if applied $[\mathrm{TBA}]=50,000 \mu \mathrm{M}$.

\begin{tabular}{|c|c|c|c|c|c|c|c|c|c|}
\hline \multirow[b]{3}{*}{ Compound } & \multicolumn{9}{|c|}{$k_{\text {initial }}\left(\mathrm{s}^{-1}\right)$} \\
\hline & \multicolumn{3}{|c|}{$\mathrm{pH}=\mathbf{3 . 0}$} & \multicolumn{3}{|c|}{$\mathrm{pH}=4.0$} & \multicolumn{3}{|c|}{$\mathrm{pH}=5.0$} \\
\hline & $\begin{array}{c}\boldsymbol{k}_{\text {initial }} \\
\text { (W/O TBA) }\end{array}$ & $\begin{array}{c}k_{\text {initial }} \\
\text { W/ TBA }\end{array}$ & $\begin{array}{c}\boldsymbol{k}_{\text {initial }} / \\
\boldsymbol{k}_{\text {initial, TBA }}\end{array}$ & $\begin{array}{c}\boldsymbol{k}_{\text {initial }} \\
\text { (W/O TBA) }\end{array}$ & $\begin{array}{c}k_{\text {initial }} \\
\text { W/ TBA }\end{array}$ & $\begin{array}{c}\boldsymbol{k}_{\text {initial }} / \\
\boldsymbol{k}_{\text {initial, TBA }}\end{array}$ & $\begin{array}{c}k_{\text {initial }} \\
(\mathbf{W} / \mathbf{O} \text { TBA) }\end{array}$ & $\begin{array}{c}k_{\text {initial }} \\
\text { W/ TBA }\end{array}$ & $\begin{array}{c}\boldsymbol{k}_{\text {initial }} / \\
\boldsymbol{k}_{\text {initial, TBA }}\end{array}$ \\
\hline $\mathrm{MB}$ & $1.75 \pm 0.05$ & $1.66 \pm 0.03$ & 1.1 & $0.48 \pm 0.06$ & $0.47 \pm 0.06$ & 1.0 & $0.34 \pm 0.02$ & $0.35 \pm 0.01$ & 1.0 \\
\hline NPX & $2.33 \pm 0.30$ & $1.87 \pm 0.21$ & 1.2 & $1.74 \pm 0.17$ & $1.49 \pm 0.09$ & 1.2 & $1.10 \pm 0.05$ & $1.08 \pm 0.06$ & 1.0 \\
\hline \multirow[t]{2}{*}{ BPA } & $0.75 \pm 0.05$ & $0.62 \pm 0.04$ & 1.2 & $0.55 \pm 0.05$ & $0.47 \pm 0.06$ & 1.2 & $0.38 \pm 0.02$ & $0.37 \pm 0.02$ & 1.0 \\
\hline & \multicolumn{3}{|c|}{$\mathrm{pH}=6.1$} & \multicolumn{3}{|c|}{$\mathrm{pH}=7.1$} & \multicolumn{3}{|c|}{$\mathrm{pH}=8.2$} \\
\hline MB & $0.24 \pm 0.01$ & $0.22 \pm 0.01$ & 1.1 & $0.20 \pm 0.02$ & $0.17 \pm 0.01$ & 1.1 & $0.17 \pm 0.01$ & $0.15 \pm 0.01$ & 1.1 \\
\hline NPX & $1.02 \pm 0.05$ & $0.96 \pm 0.03$ & 1.1 & $0.83 \pm 0.03$ & $0.69 \pm 0.03$ & 1.2 & $0.51 \pm 0.03$ & $0.49 \pm 0.04$ & 1.0 \\
\hline BPA & $0.31 \pm 0.01$ & $0.31 \pm 0.01$ & 1.0 & $0.32 \pm 0.01$ & $0.30 \pm 0.01$ & 1.1 & $0.21 \pm 0.01$ & $0.20 \pm 0.01$ & 1.1 \\
\hline
\end{tabular}

Rate constants obtained from linear regression of all data points of replicate experiments and reported with standard error. 
Table S8. Initial first-order rate constants $\left(k_{\text {initial }}\right)$ of degradation of MB by Fe(II)/PAA depending on different molar ratios of PAA to Fe(II) or $\mathrm{H}_{2} \mathrm{O}_{2}$ at initial $\mathrm{pH} 3.0$ and $22{ }^{\circ} \mathrm{C}\left(\mathrm{R}^{2}>0.95\right)$.

\begin{tabular}{cccccc}
\hline $\begin{array}{c}\text { Moral ratio } \\
\left(\mathbf{P A A} / \mathbf{H}_{2} \mathbf{O}_{2} / \mathbf{F e}(\mathbf{I I})\right)\end{array}$ & $\boldsymbol{k}_{\text {initial }}\left(\mathbf{s}^{-\mathbf{1}}\right)$ & $\begin{array}{c}\text { Moral ratio } \\
\left(\mathbf{P A A} / \mathbf{H}_{2} \mathbf{O}_{2} / \mathbf{F e}(\mathbf{I I})\right)\end{array}$ & $\boldsymbol{k}_{\text {initial }}\left(\mathbf{s}^{\mathbf{- 1}}\right)$ & $\begin{array}{c}\text { Moral ratio } \\
\left(\mathbf{P A A} / \mathbf{H}_{2} \mathbf{O}_{2} / \mathbf{F e}(\mathbf{I I})\right)\end{array}$ & $\boldsymbol{k}_{\text {initial }}\left(\mathbf{s}^{-\mathbf{1}}\right)$ \\
\hline $\mathbf{5 0 : 1 5 : 2 0}$ & $1.09 \pm 0.13$ & $\mathbf{1 0 0 : 3 1 : 1 0 0}$ & $1.75 \pm 0.05$ & $\mathbf{1 0 0 : 1 0 0 : 1 0 0}$ & $1.93 \pm 0.03$ \\
$\mathbf{5 0 : 1 5 : 5 0}$ & $1.15 \pm 0.16$ & $\mathbf{5 0 0 : 1 5 5 : 1 0 0}$ & $1.09 \pm 0.13$ & $\mathbf{1 0 0 : 2 0 0 : 1 0 0}$ \\
$\mathbf{5 0 : 1 5 : 1 0 0}$ & $1.18 \pm 0.06$ & $\mathbf{1 0 0 0 : 3 1 0 : 1 0 0}$ & $0.36 \pm 0.04$ & & \\
$\mathbf{5 0 : 1 5 : 5 0 0}$ & $0.90 \pm 0.05$ & & & \\
\hline
\end{tabular}

Rate constants obtained from linear regression of all data points of replicate experiments and reported with standard error. 
Table S9. LC-MS-TOF high resolution accurate mass data. ${ }^{\mathrm{a}}$

\begin{tabular}{|c|c|c|c|c|}
\hline Parent compound & Retention time (min) & Molecular formula & Measured mass $(\mathrm{m} / \mathrm{z})$ & Ion fragments $^{b}$ \\
\hline \multirow[t]{5}{*}{ Methylene blue } & $9.5(\mathrm{MB})$ & $\mathrm{C}_{16} \mathrm{H}_{18} \mathrm{~N}_{3} \mathrm{~S}^{+}$ & 284.1227 & $\mathrm{C}_{15} \mathrm{H}_{16} \mathrm{~N}_{3} \mathrm{~S}^{+}\left(-\mathrm{CH}_{2}\right) 270.1063$ \\
\hline & 9.1 & $\mathrm{C}_{16} \mathrm{H}_{18} \mathrm{~N}_{3} \mathrm{O}_{3} \mathrm{~S}^{+}$ & 332.1051 & $\mathrm{C}_{15} \mathrm{H}_{16} \mathrm{~N}_{3} \mathrm{O}_{3} \mathrm{~S}^{+}\left(-\mathrm{CH}_{2}\right) 318.0888$ \\
\hline & 9.4 & $\mathrm{C}_{16} \mathrm{H}_{18} \mathrm{~N}_{3} \mathrm{OS}^{+}$ & 300.1183 & $\mathrm{C}_{15} \mathrm{H}_{16} \mathrm{~N}_{3} \mathrm{OS}^{+}\left(-\mathrm{CH}_{2}\right) 286.1035$ \\
\hline & 8.6 & $\mathrm{C}_{14} \mathrm{H}_{14} \mathrm{~N}_{3} \mathrm{~S}^{+}$ & 256.0908 & $\mathrm{C}_{14} \mathrm{H}_{12} \mathrm{~N}_{2} \mathrm{~S}^{+}\left(-\mathrm{NH}_{2}\right) 240.0718$ \\
\hline & 4.0 & $\mathrm{C}_{6} \mathrm{H}_{5} \mathrm{O}_{3} \mathrm{~S}$ & 158.0032 & $\mathrm{C}_{6} \mathrm{H}_{5} \mathrm{O}\left(-\mathrm{SO}_{2}\right) 94.0403$ \\
\hline \multirow[t]{5}{*}{ Naproxen } & $11.1(\mathrm{NPX})$ & $\mathrm{C}_{14} \mathrm{H}_{14} \mathrm{O}_{3}$ & 231.1023 & $\mathrm{C}_{13} \mathrm{H}_{12} \mathrm{O}\left(-\mathrm{CH}_{2} \mathrm{O}_{2}\right) 185.0968$ \\
\hline & 10.0 & $\mathrm{C}_{14} \mathrm{H}_{14} \mathrm{O}_{4}$ & 247.0971 & $\mathrm{C}_{13} \mathrm{H}_{12} \mathrm{O}_{2}\left(-\mathrm{CH}_{2} \mathrm{O}_{2}\right) 201.0916$ \\
\hline & 9.2 & $\mathrm{C}_{13} \mathrm{H}_{12} \mathrm{O}_{4}$ & 233.0817 & $\mathrm{C}_{13} \mathrm{H}_{11} \mathrm{O}_{3}(-\mathrm{HO}) 216.0778$ \\
\hline & 10.7 & $\mathrm{C}_{13} \mathrm{H}_{12} \mathrm{O}_{3}$ & 217.0868 & $\mathrm{C}_{12} \mathrm{H}_{9} \mathrm{O}\left(-\mathrm{CH}_{3} \mathrm{O}_{2}\right) 170.0729$ \\
\hline & 11.6 & $\mathrm{C}_{13} \mathrm{H}_{12} \mathrm{O}_{2}$ & 201.0910 & $\mathrm{C}_{13} \mathrm{H}_{12} \mathrm{O}(-\mathrm{O}) 185.0957$ \\
\hline \multirow[t]{6}{*}{ Bisphenol } & $10.2(\mathrm{BPA})$ & $\mathrm{C}_{15} \mathrm{H}_{16} \mathrm{O}_{2}$ & 227.1088 & $\mathrm{C}_{14} \mathrm{H}_{13} \mathrm{O}_{2}\left(-\mathrm{CH}_{3}\right) 212.0846$ \\
\hline & 8.7 & $\mathrm{C}_{14} \mathrm{H}_{14} \mathrm{O}_{4}$ & 245.0828 & $\mathrm{C}_{14} \mathrm{H}_{14} \mathrm{O}_{3}(-\mathrm{O}) 229.0869$ \\
\hline & 9.8 & $\mathrm{C}_{15} \mathrm{H}_{16} \mathrm{O}_{3}$ & 243.1033 & $\mathrm{C}_{14} \mathrm{H}_{13} \mathrm{O}_{3}\left(-\mathrm{CH}_{3}\right) 228.0792$ \\
\hline & 9.0 & $\mathrm{C}_{15} \mathrm{H}_{14} \mathrm{O}_{3}$ & 241.0888 & $\mathrm{C}_{14} \mathrm{H}_{11} \mathrm{O}_{3}\left(-\mathrm{CH}_{3}\right) 226.0648$ \\
\hline & 9.6 & $\mathrm{C}_{9} \mathrm{H}_{10} \mathrm{O}_{2}$ & 149.0602 & $\mathrm{C}_{8} \mathrm{H}_{8} \mathrm{O}_{2}\left(-\mathrm{CH}_{2}\right) 135.0438$ \\
\hline & 8.0 & $\mathrm{C}_{8} \mathrm{H}_{8} \mathrm{O}_{2}$ & 135.0455 & $\mathrm{C}_{6} \mathrm{H}_{6} \mathrm{O}_{0}\left(-\mathrm{C}_{2} \mathrm{H}_{2} \mathrm{O}\right) 93.0346$ \\
\hline
\end{tabular}

${ }^{a}$ Relative error (ppm) for all compounds is less than $10 \mathrm{ppm}$.

${ }^{\mathrm{b}}$ Ion fragments detected at 140, 180, 220, and $250 \mathrm{eV}$. 
Table S10. Predicted acute and chronic toxicity ${ }^{\mathrm{a}}$ of parent compounds and their reaction products by $\mathrm{Fe}(\mathrm{II}) / \mathrm{PAA}$ process using ECOSAR program.

\begin{tabular}{lllllll}
\hline \multirow{2}{*}{$\begin{array}{c}\text { Compounds } \\
\mathrm{m} / \mathrm{z}\end{array}$} & \multicolumn{3}{c}{ Acute toxicity $\left(\mathrm{mg} \cdot \mathrm{L}^{-1}\right)$} & \multicolumn{2}{c}{ Chronic toxicity $\left(\mathrm{mg} \cdot \mathrm{L}^{-1}\right): \mathrm{ChV}$} \\
\cline { 2 - 7 } & $\begin{array}{c}\text { Fish } \\
\left(\mathrm{LC}_{50}\right)\end{array}$ & $\begin{array}{c}\text { Daphnid } \\
\left(\mathrm{LC}_{50}\right)\end{array}$ & $\begin{array}{c}\text { Green algae } \\
\left(\mathrm{EC}_{50}\right)\end{array}$ & Fish & Daphnid & $\begin{array}{c}\text { Green } \\
\text { algae }\end{array}$ \\
\hline $284.1227(\mathrm{MB})$ & 5.79 & 3.88 & 5.72 & 0.688 & 0.599 & 2.16 \\
$332.1051^{\mathrm{b}}$ & 11.1 & 75.4 & 5.31 & 5.77 & 27.6 & 0.748 \\
$300.1183^{\mathrm{b}}$ & 21.3 & 2.49 & 6.26 & 0.196 & 0.031 & 1.56 \\
256.0908 & 9.75 & 1.76 & 4.09 & 0.074 & 0.023 & 0.835 \\
158.0032 & $9.05 \times 10^{5}$ & $3.83 \times 10^{5}$ & $8.53 \times 10^{4}$ & $6.26 \times 10^{4}$ & $1.66 \times 10^{4}$ & $1.16 \times 10^{4}$ \\
\hline 231.1023 (NPX) & 193 & 122 & 138 & 21.3 & 15.7 & 45.3 \\
$247.0971^{\mathrm{b}}$ & 125 & 71.9 & 11.3 & 13.2 & 8.77 & 8.0 \\
$233.0817^{\mathrm{b}}$ & 114 & 874 & 46.4 & 62.3 & 326 & 6.26 \\
217.0868 & 125 & 69.1 & 11.2 & 13.1 & 8.32 & 27.1 \\
201.0910 & 199 & 124 & 136 & 21.7 & 15.7 & 44.1 \\
\hline 227.1088 (BPA) & 1.28 & 5.24 & 1.33 & 0.550 & 1.77 & 0.227 \\
245.0828 & 9.54 & 67.0 & 4.40 & 5.03 & 24.6 & 0.613 \\
$243.1033^{b}$ & 2.65 & 13.1 & 2.07 & 1.22 & 4.57 & 0.329 \\
241.0888 & 9.54 & 67.0 & 4.40 & 5.03 & 24.6 & 0.613 \\
149.0602 & 4.15 & 26.9 & 2.16 & 2.12 & 9.76 & 0.311 \\
135.0455 & 66.5 & 30.0 & 5.68 & 6.07 & 2.90 & 9.95 \\
\hline
\end{tabular}

${ }^{a}$ Toxicity was classified based on the Globally Harmonized System of Classification and Labeling of Chemicals. Very toxic (Red): $\mathrm{LC}_{50} / \mathrm{EC}_{50} / \mathrm{ChV} \leq 1 \mathrm{mg} \mathrm{L}^{-1}$, Toxic (Pink): $1 \mathrm{mg} \mathrm{L}^{-1}<\mathrm{LC}_{50} / \mathrm{EC}_{50} / \mathrm{ChV} \leq 10$ mg L-1 Harmful (Yellow): $10 \mathrm{mg} \mathrm{L}^{-1}<\mathrm{LC}_{50} / \mathrm{EC}_{50} / \mathrm{ChV} \leq 100 \mathrm{mg} \mathrm{L}^{-1}$, Not harmful (Green): $\mathrm{LC}_{50} / \mathrm{EC}_{50} / \mathrm{ChV}>100 \mathrm{mg} \mathrm{L}^{-1}$.

${ }^{\mathrm{b}}$ In case that exact structure of proposed product is not clear, the highest toxicity from possible structures is indicated. 


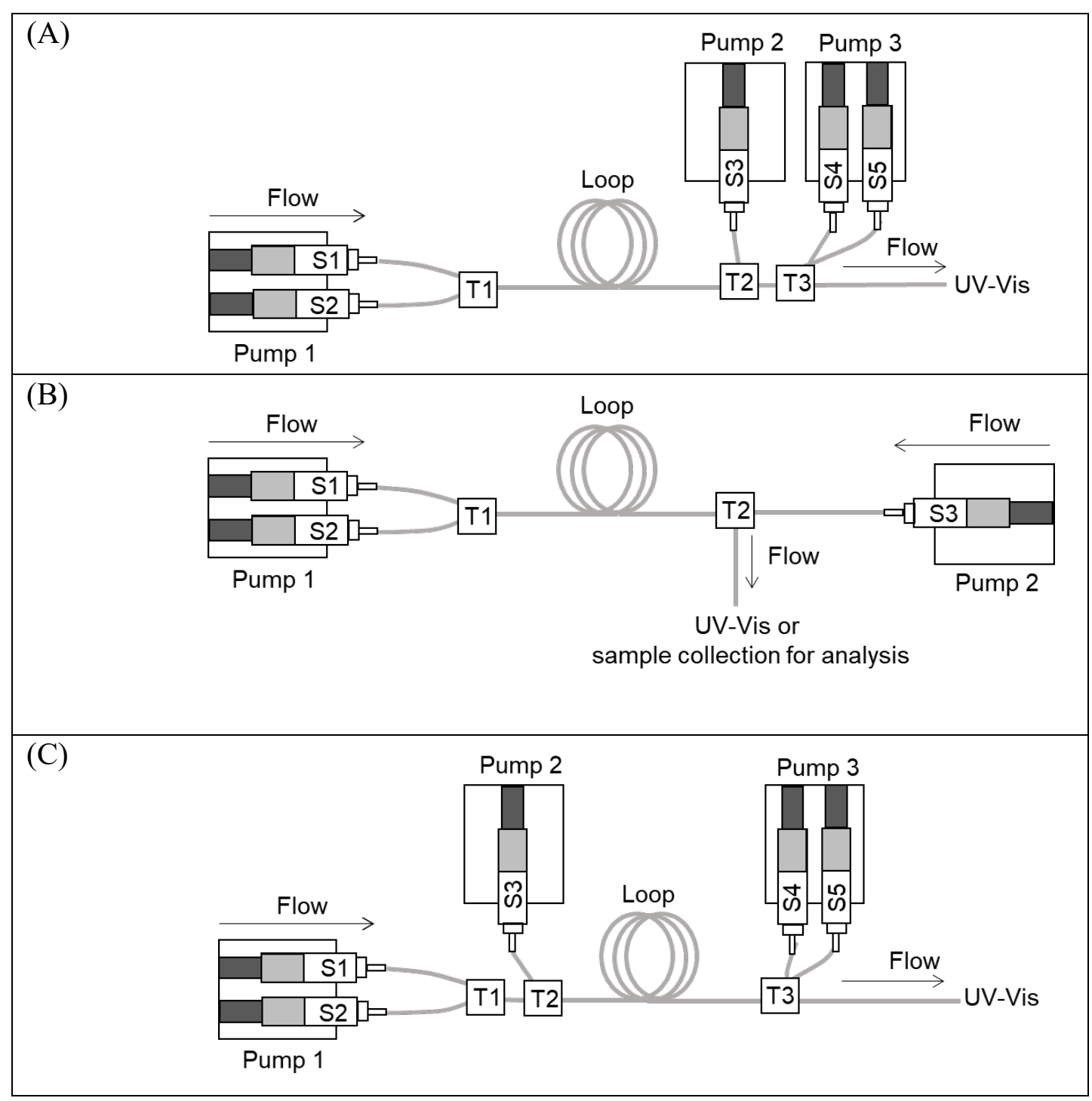

Figure S1. Quenched flow system (QFS) design: (A) PAA decomposition experiments (B) target compound degradation experiments $(\mathrm{C})$ validation tests. 


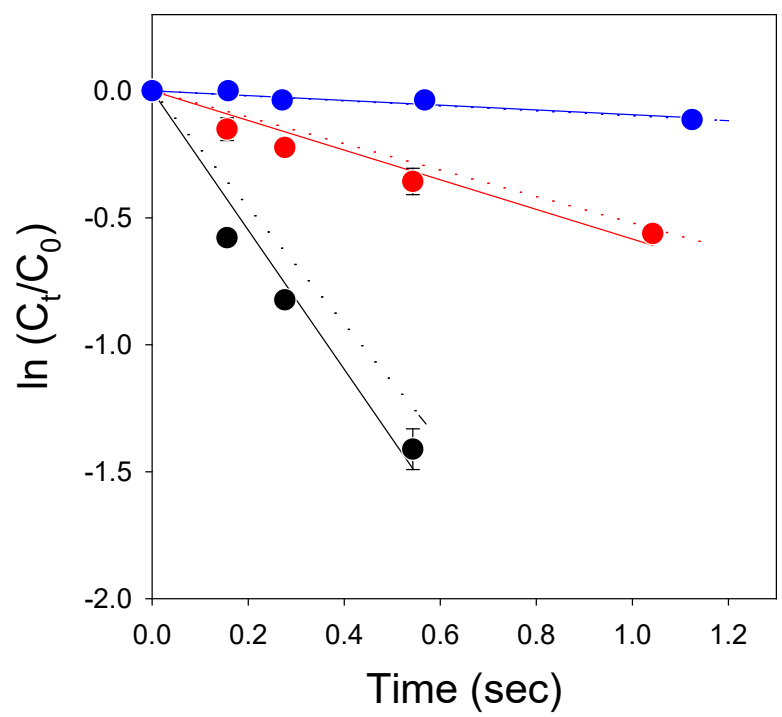

- Triclosan, $\left.\mathrm{pH} 7.5,{ }^{-}\right]_{0}^{-}=10 \square \mathrm{M}$

- BPA, pH 7.5, $\left[\mathrm{I}^{-}\right]_{0}=4 \square \mathrm{M}$

- BPA, pH 9.0, $\left[\mathrm{I}^{-}\right]_{0}=10 \square \mathrm{M}$

from reference

from reference

- from reference

Figure S2. First-order rate constants obtained in experiments of BPA or triclosan reactivities in chlorine solution containing iodide. Rate constants were determined by measuring the decrease of oxidant concentration using the QFS and DPD method. Error bars mean the standard deviation at each point. Dashed lines represent the kinetic values $\left(0.098,0.50,2.3 \mathrm{sec}^{-1}\right.$ for blue, red and black, respectively) reported from reference. ${ }^{2}$ The observed rate constants (termed $k_{\text {initial }}$ ) using the QFS in this study were $0.095 \pm$ $0.002,0.51 \pm 0.06$ and $2.74 \pm 0.17 \mathrm{sec}^{-1}$ for triclosan at $\mathrm{pH} 7.5$, BPA at $\mathrm{pH} 7.5$, and BPA at $\mathrm{pH} 9.0$, respectively $\left(\mathrm{R}^{2}>0.92\right)$. Reaction condition: $[\mathrm{BPA}]_{0}=100 \mu \mathrm{M}$, [triclosan $]_{0}$ $=25 \mu \mathrm{M},[\mathrm{NaOCl}]_{0}=10 \mu \mathrm{M},\left[\mathrm{I}^{-}\right]_{0}=4$ or $10 \mu \mathrm{M}$, [sodium bicarbonate $]=2 \times 10^{3} \mu \mathrm{M}$, $\mathrm{pH}=7.5$ or 9.0 . 

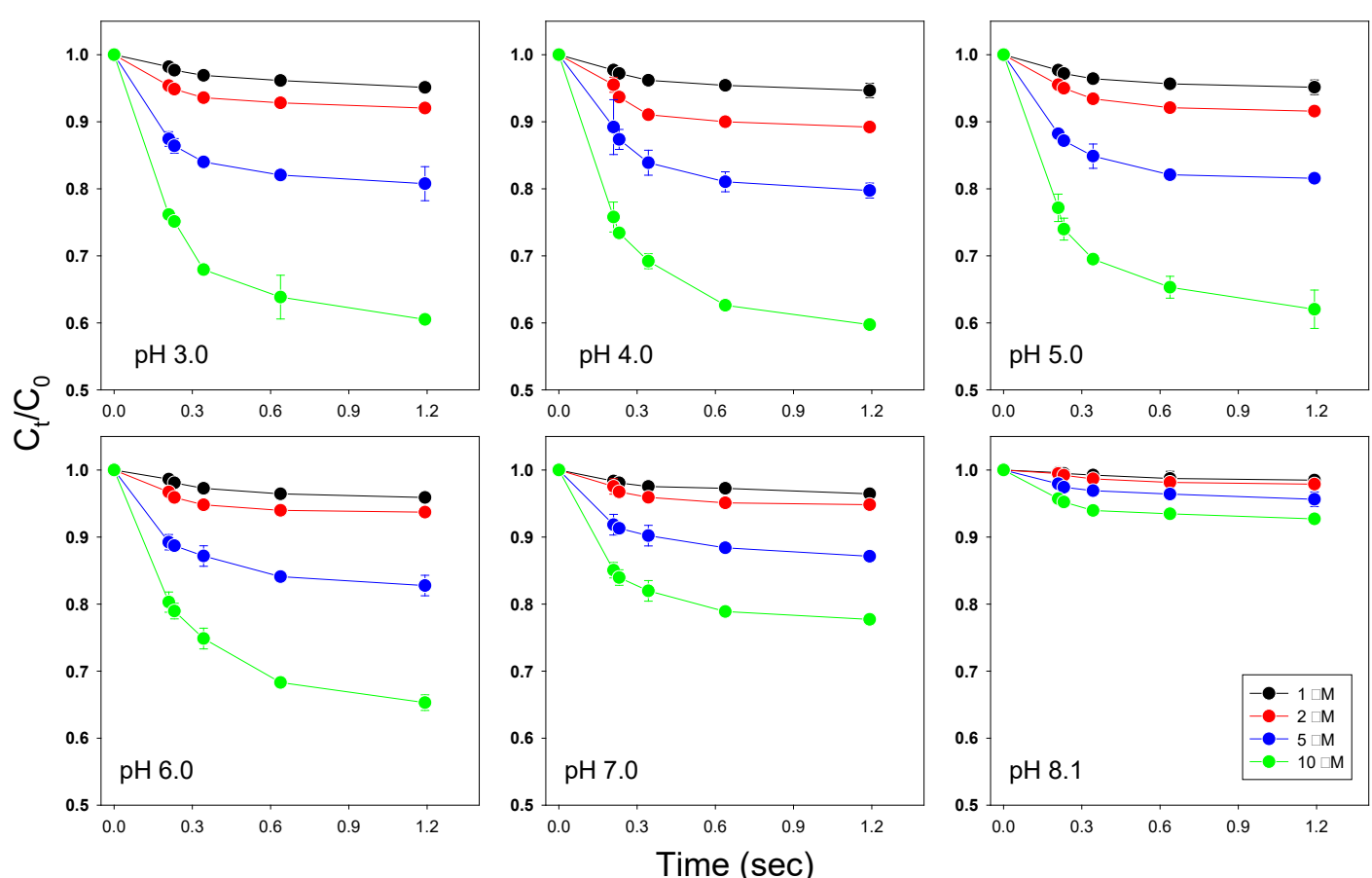

Figure S3. Kinetics of PAA decomposition by different concentrations of Fe(II) at initial pH 3.0-8.1 and $22^{\circ} \mathrm{C}$. Reaction conditions: $[\mathrm{PAA}]_{0}=20$ $\mu \mathrm{M},[\mathrm{Fe}(\mathrm{II})]_{0}=1,2,5$, and $10 \mu \mathrm{M}$. Error bars of each data point indicate the standard deviation. The amount of PAA consumption was proportionally related to $\mathrm{Fe}(\mathrm{II})$ concentration: at $[\mathrm{Fe}(\mathrm{II})]_{0} /[\mathrm{PAA}]_{0}=0.5,0.25,0.1$ and 0.05 , PAA loss was around $40 \%, 20 \%, 8 \%$ and $3 \%$, respectively. This suggests that once Fe(II) was nearly consumed, PAA decomposition almost halted or became very slow. However, the percentage of PAA consumption was slightly less than the $[\mathrm{Fe}(\mathrm{II})]_{0} /[\mathrm{PAA}]_{0}$, suggesting that some loss of $\mathrm{Fe}(\mathrm{II})$ was due to reactions by radicals and/or Fe(IV), not just by PAA only. Overall, these results indicate that PAA's rapid decay is mostly due to reaction with $\mathrm{Fe}^{2+}$. 


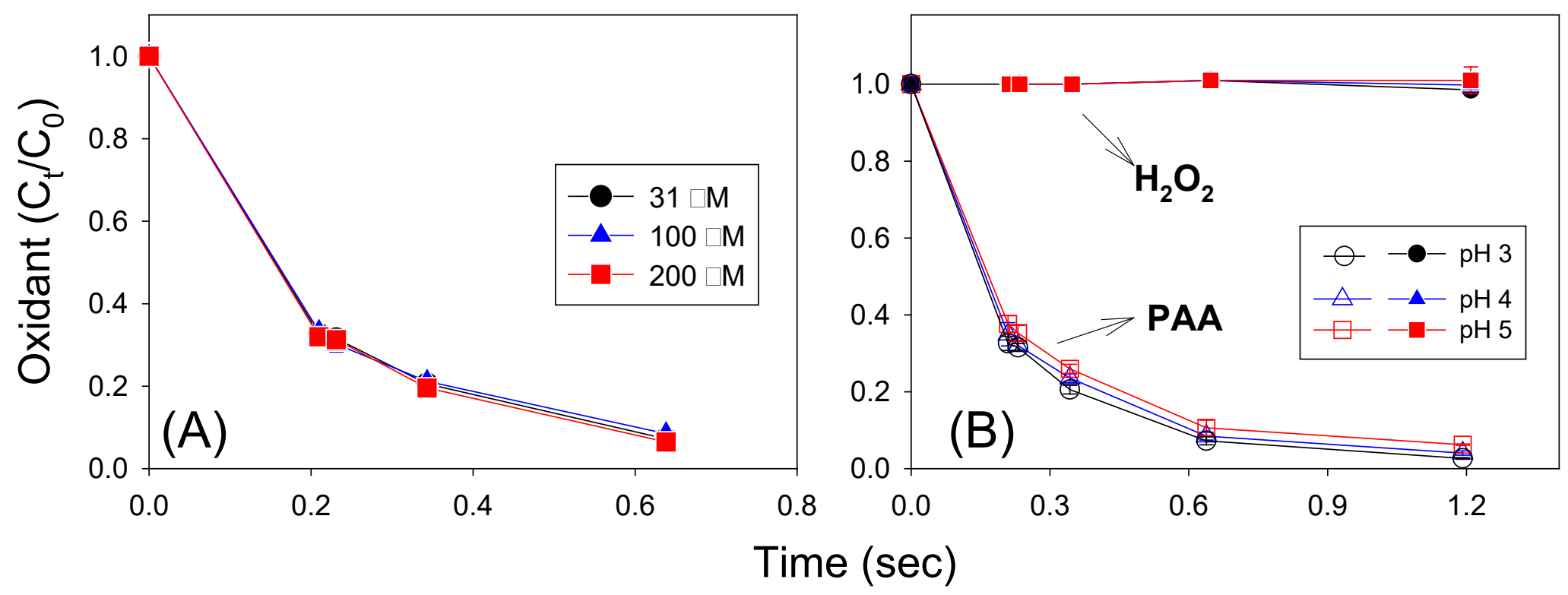

Figure S4. (A) Kinetics of PAA decomposition by $\mathrm{Fe}(\mathrm{II})$ in the presence of different concentrations of $\mathrm{H}_{2} \mathrm{O}_{2}$ at initial $\mathrm{pH} 3.0$ and $22^{\circ} \mathrm{C}\left(\mathrm{R}^{2}>0.98\right)$. Reaction condition: $[\mathrm{PAA}]_{0}=100 \mu \mathrm{M},[\mathrm{Fe}(\mathrm{II})]_{0}=100 \mu \mathrm{M},\left[\mathrm{H}_{2} \mathrm{O}_{2}\right]_{0}=31,100,200 \mu \mathrm{M}$. (B) Decomposition of PAA and $\mathrm{H}_{2} \mathrm{O}_{2}$ in Fe(II)/PAA system: $[\mathrm{PAA}]_{0}=100 \mu \mathrm{M},\left[\mathrm{H}_{2} \mathrm{O}_{2}\right]_{0}=31 \mu \mathrm{M}$ (in PAA solution), $[\mathrm{Fe}(\mathrm{II})]_{0}=100 \mu \mathrm{M}$, initial $\mathrm{pH}$ 3.0-5.0. Error bars of each data point indicate the standard deviation. 

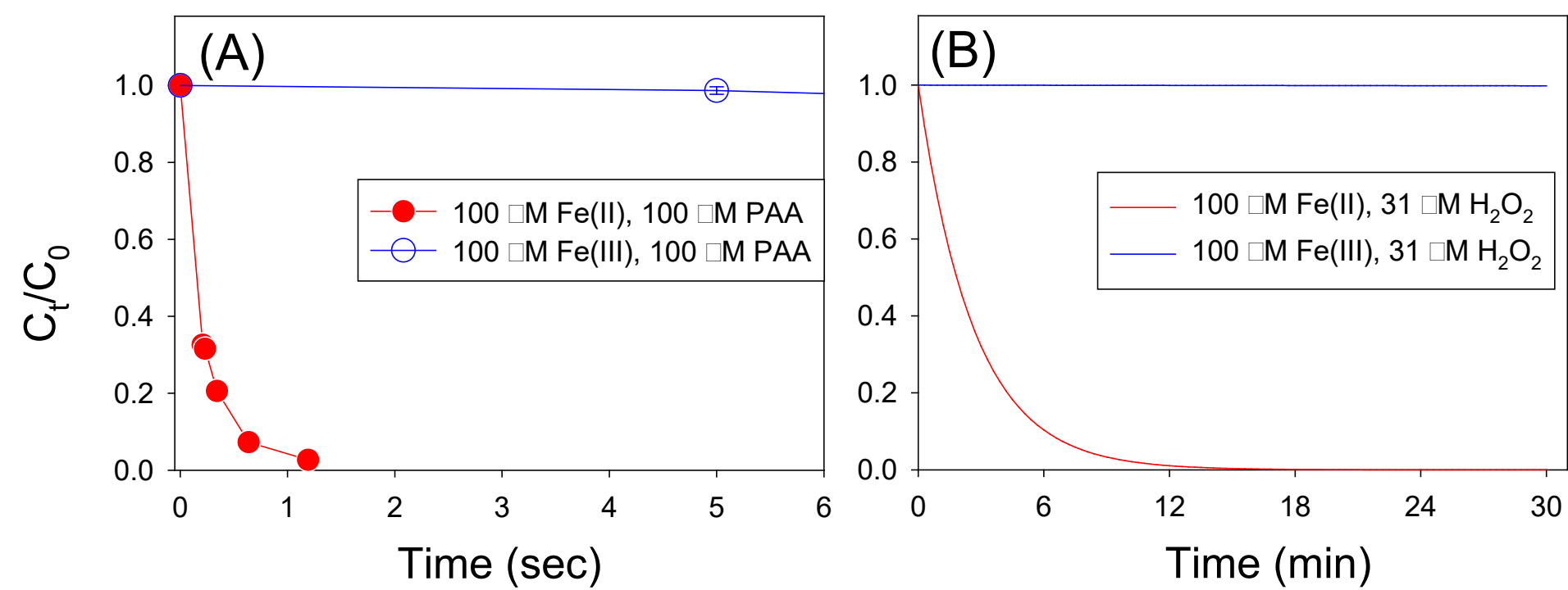

Figure S5. (A) PAA decomposition by Fe(II) or Fe(III). Reaction conditions: [Fe(II) or Fe(III) $]_{0}=100 \mu \mathrm{M},[\mathrm{PAA}]_{0}=100 \mu \mathrm{M}$, initial pH 3.0, $22^{\circ} \mathrm{C}$. (B) $\mathrm{H}_{2} \mathrm{O}_{2}$ decomposition by $\mathrm{Fe}(\mathrm{II})$ or $\mathrm{Fe}(\mathrm{III})$, calculated based on published $k$ values $\left(k \mathrm{Fe}(\mathrm{II})=63 \mathrm{M}^{-1} \mathrm{~s}^{-1}, k \mathrm{Fe}(\mathrm{III})=1.0 \times 10^{-2} \mathrm{M}^{-1} \mathrm{~s}^{-1}\right){ }^{20,23}$ Error bars of each data point indicate the standard deviation. 


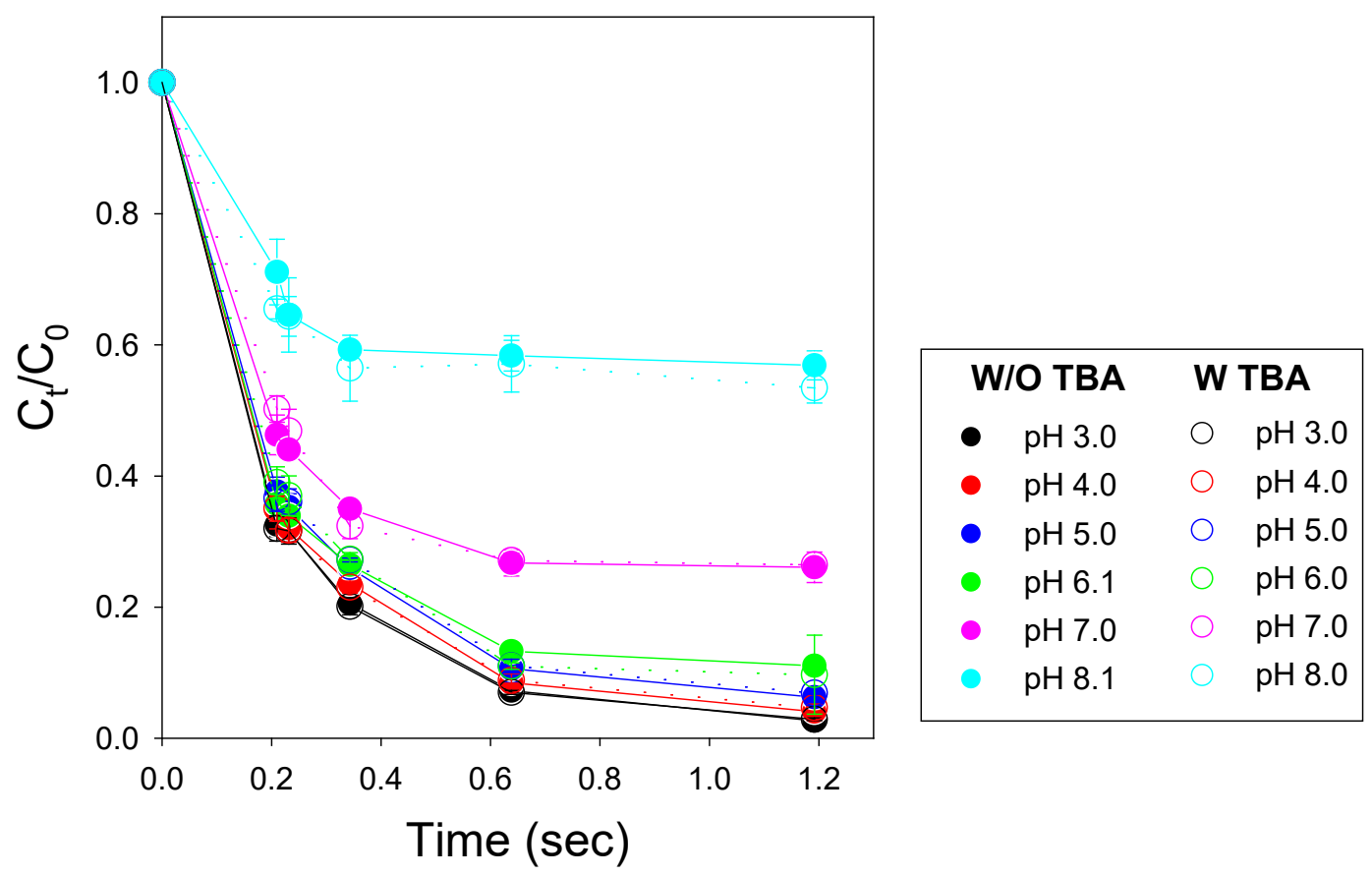

Figure S6. PAA decomposition by $\mathrm{Fe}(\mathrm{II})$ at initial $\mathrm{pH}$ 3.0-8.1 with and without TBA addition. Reaction conditions: $[\mathrm{PAA}]_{0}=100 \mu \mathrm{M},[\mathrm{Fe}(\mathrm{II})]_{0}=100 \mu \mathrm{M}$, and if applied $[\mathrm{TBA}]=50,000 \mu \mathrm{M}$. Error bars mean the standard deviation at each point. 

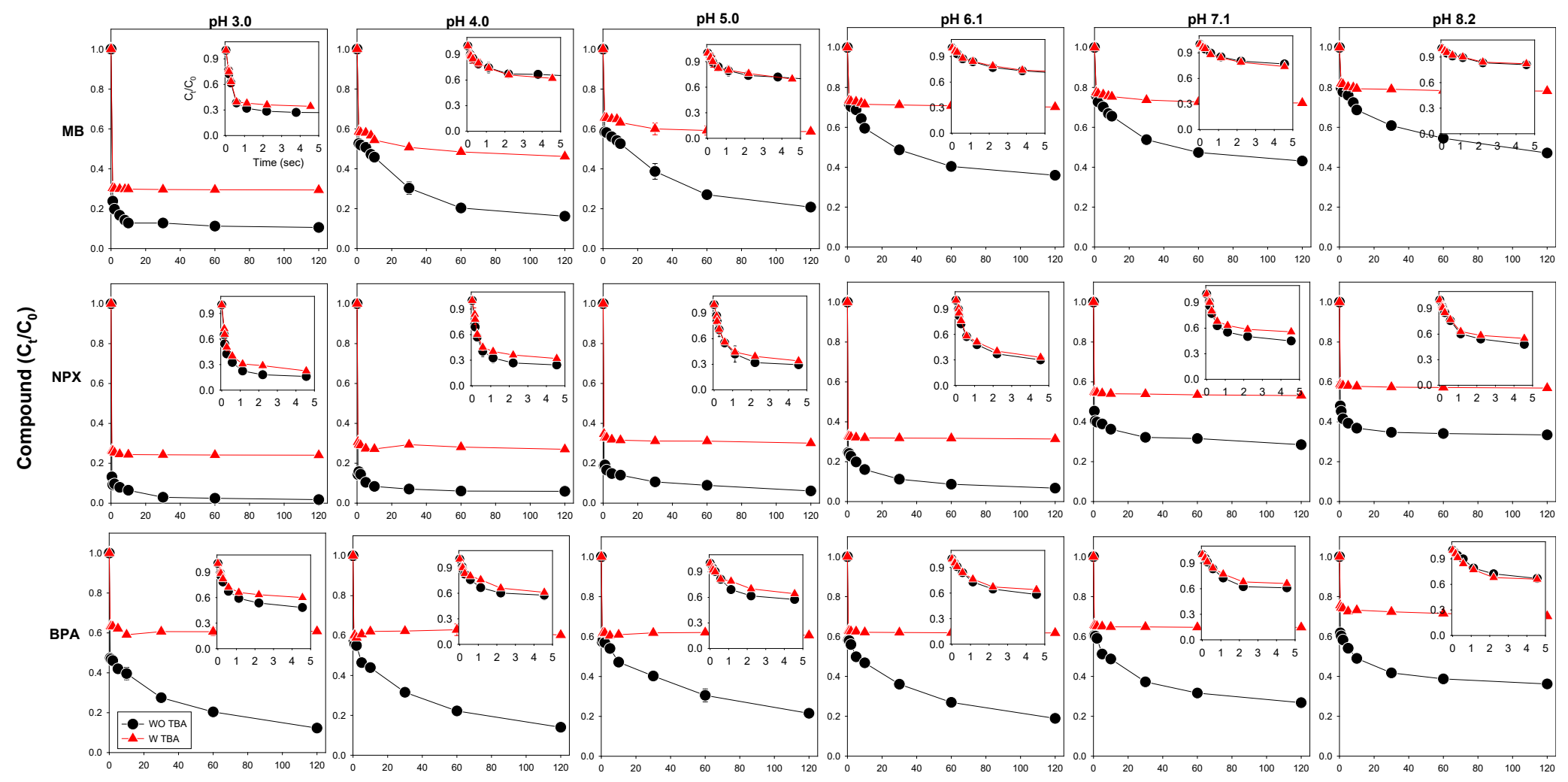

Time $(\min )$

Figure S7. Degradation of MB, NPX, and BPA by the Fe(II)/PAA process at initial $\mathrm{pH} 3.0-8.2$ and $22^{\circ} \mathrm{C}$ with and without TBA addition. Longduration oxidation was conducted in batch reactors, and short-duration oxidation (insert in Figure) was conducted using a quenched flow system. Reaction conditions: [compound $]_{0}=15 \mu \mathrm{M},[\mathrm{PAA}]_{0}=100 \mu \mathrm{M},[\mathrm{Fe}(\mathrm{II})]_{0}=100 \mu \mathrm{M}$, and if applied $[\mathrm{TBA}]=50,000 \mu \mathrm{M}$. Error bars of each data point indicate the standard deviation. 

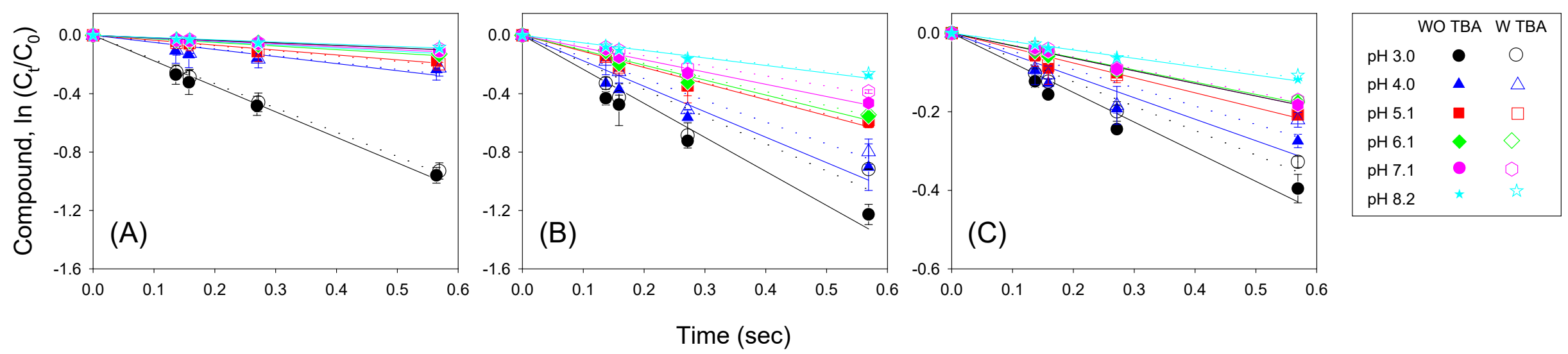

Figure S8. Initial reaction kinetics of (A) MB, (B) NPX, and (C) BPA by Fe(II)/PAA process at initial pH 3.0-8.2 at $22^{\circ} \mathrm{C}$ with and without TBA addition $\left(\mathrm{R}^{2}>0.93\right)$. Reaction conditions: $[\text { compound }]_{0}=15 \mu \mathrm{M},[\mathrm{PAA}]_{0}=100 \mu \mathrm{M},[\mathrm{Fe}(\mathrm{II})]_{0}=100 \mu \mathrm{M}$, and if applied $[\mathrm{TBA}]=50,000 \mu \mathrm{M}$. Filled symbols: without TBA; open symbols: with TBA. Error bars of each data point indicate the standard deviation. 

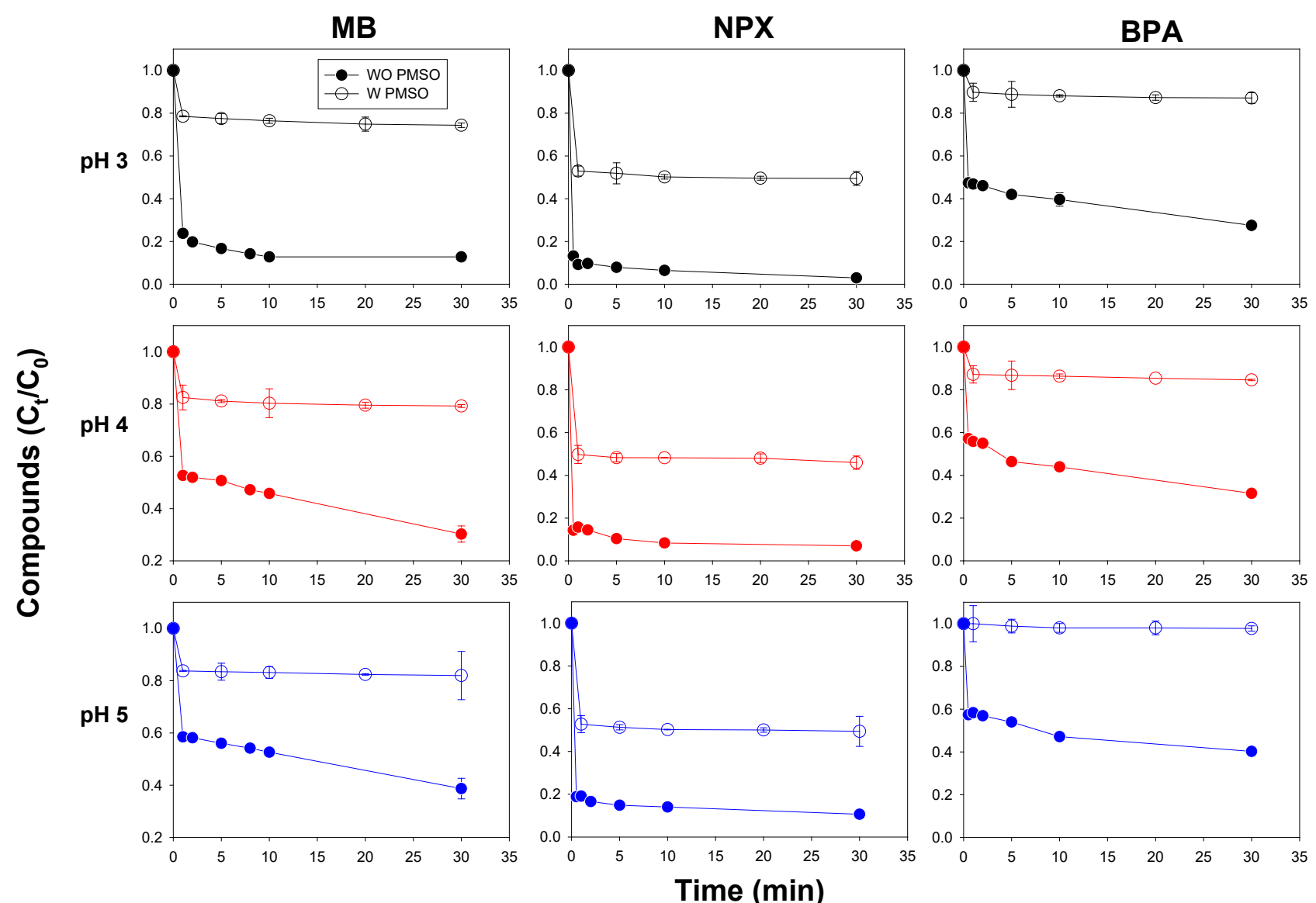

Figure S9. Degradation of MB, NPX, and BPA by the Fe(II)/PAA process at initial $\mathrm{pH} 3.0-5.0$ and $22^{\circ} \mathrm{C}$ with and without PMSO addition. Reaction conditions: [compound $]_{0}=15 \mu \mathrm{M},[\mathrm{PAA}]_{0}=100 \mu \mathrm{M},[\mathrm{Fe}(\mathrm{II})]_{0}=100 \mu \mathrm{M}$, and if applied [PMSO $]_{0}=1,000 \mu \mathrm{M}$. Error bars of each data point indicate the standard deviation. 


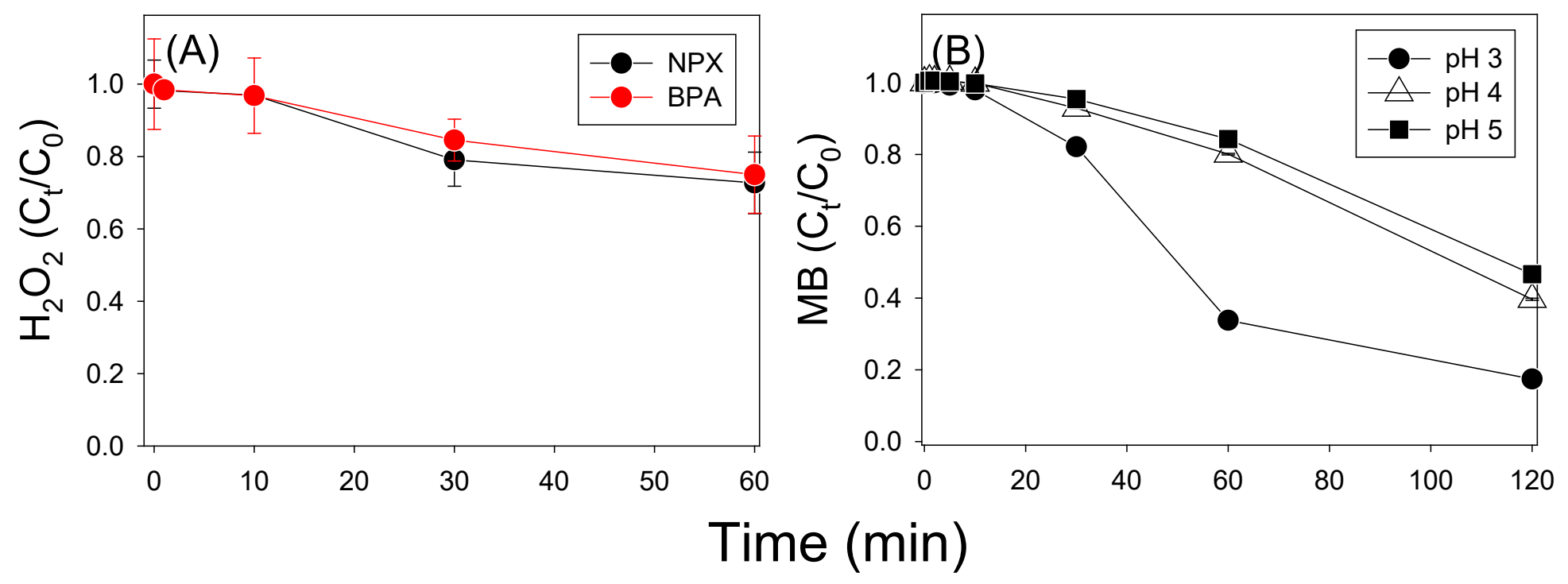

Figure S10. (A) $\mathrm{H}_{2} \mathrm{O}_{2}$ decomposition in $\mathrm{Fe}(\mathrm{II}) / \mathrm{PAA}$ process over time $\left([\mathrm{Fe}(\mathrm{II})]_{0}=100 \mu \mathrm{M} \text {, }[\mathrm{PAA}]_{0}=100 \mu \mathrm{M} \text {, [compound }\right]_{0}=15 \mu \mathrm{M}$, initial pH $\left.3.0,22^{\circ} \mathrm{C}\right)$. (B) $\mathrm{MB}$ degradation in $\mathrm{Fe}(\mathrm{III}) / \mathrm{H}_{2} \mathrm{O}_{2}$ process over time $\left([\mathrm{Fe}(\mathrm{III})]_{0}=100 \mu \mathrm{M},\left[\mathrm{H}_{2} \mathrm{O}_{2}\right]_{0}=31 \mu \mathrm{M},[\mathrm{MB}]_{0}=15 \mu \mathrm{M}\right.$, initial pH 3.0-5.0, $22^{\circ} \mathrm{C}$ ). Error bars of each data point indicate the standard deviation. 

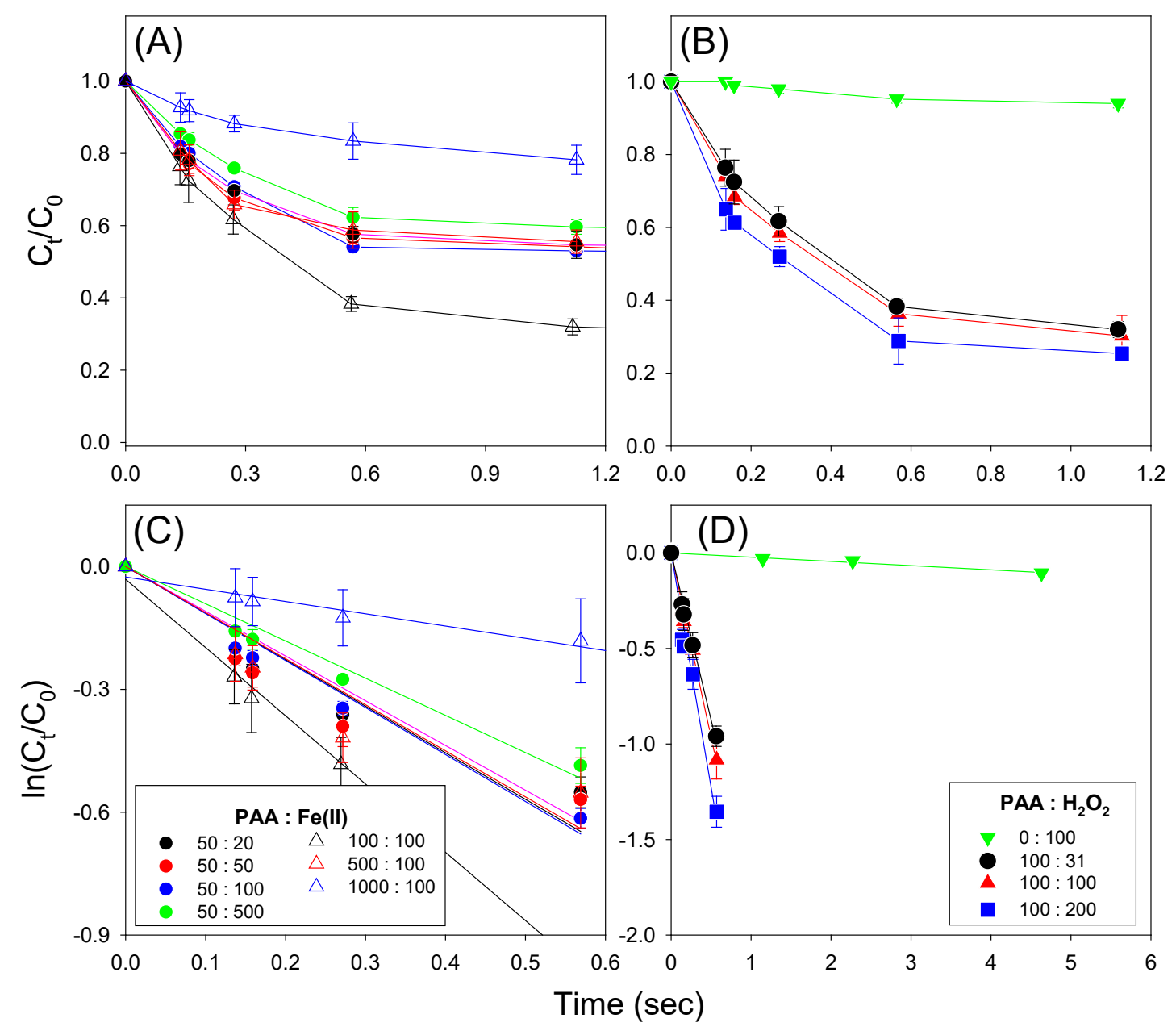

Figure S11. Fast degradation of MB by Fe(II)/PAA process with different molar ratios of (A) PAA : $\mathrm{Fe}(\mathrm{II})$ and (B) PAA : $\mathrm{H}_{2} \mathrm{O}_{2}$. (C) and (D): $\ln \left(\mathrm{C}_{t} / \mathrm{C}_{0}\right)$ versus time relationships. Experimental conditions: $(\mathrm{A})$ and $(\mathrm{C})[\mathrm{MB}]_{0}=15 \mu \mathrm{M},[\mathrm{PAA}]_{0}=50,100,500$, and 1000 $\mu \mathrm{M},[\mathrm{Fe}(\mathrm{II})]_{0}=20,50,100$, and $500 \mu \mathrm{M}, \mathrm{pH} 3.0,22^{\circ} \mathrm{C}$. (B) and (D) $[\mathrm{MB}]_{0}=15 \mu \mathrm{M}$, $[\mathrm{PAA}]_{0}=0$ or $100 \mu \mathrm{M},\left[\mathrm{H}_{2} \mathrm{O}_{2}\right]_{0}=31,100$, and $200 \mu \mathrm{M}$, initial $\mathrm{pH} 3.0,22^{\circ} \mathrm{C}$. Error bars of each data point indicate the standard deviation. 

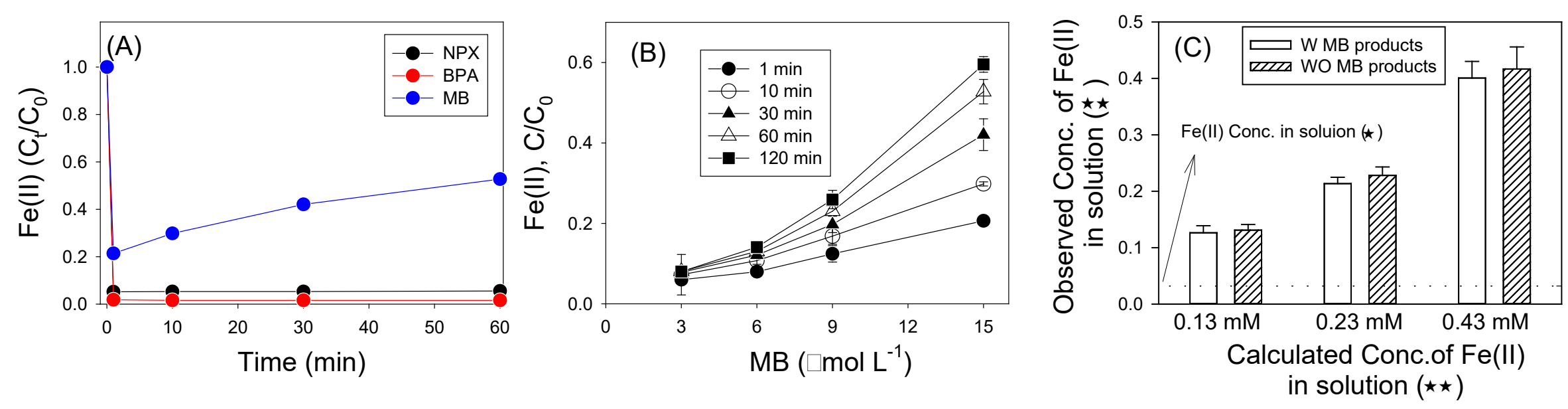

Figure S12. Change in Fe(II) concentration in Fe(II)/PAA process (A) over time ([Fe(II) $]_{0}=100 \mu \mathrm{M},[\mathrm{PAA}]_{0}=100 \mu \mathrm{M},[\text { compound }]_{0}=15 \mu \mathrm{M}$, $\left.\mathrm{pH} 3.0,22^{\circ} \mathrm{C}\right)$; (B) with different $\mathrm{MB}$ concentrations at initial $\mathrm{pH} 3.0$ and $22^{\circ} \mathrm{C}\left([\mathrm{MB}]_{0}=3,6,9\right.$, and $\left.15 \mu \mathrm{M},[\mathrm{PAA}]_{0}=100 \mu \mathrm{M},[\mathrm{Fe}]_{0}=100 \mu \mathrm{M}\right)$.

(C) Effects of MB products on determination of Fe(II) concentration using the ferrozine method. First, MB product solution ( $\star$ ) was prepared using $15 \mu \mathrm{M}$ MB, $100 \mu \mathrm{M}$ PAA and $100 \mu \mathrm{M}$ Fe(II) for 10 min reaction. After 10 min, there remained $30 \mu \mathrm{M}$ Fe(II) in MB product solution ( $\star$ ). Then, 100, 200, and $300 \mu \mathrm{M} \mathrm{Fe}(\mathrm{II})$ were added to MB product solution ( $\star$ ) to generate three solutions $(\star \star)$. The Fe(II) concentration in solutions $(\star \star)$ containing MB products was determined using the Ferrozine method, and compared to those in similar solutions without MB products. Error bars of each data point indicate the standard deviation. 

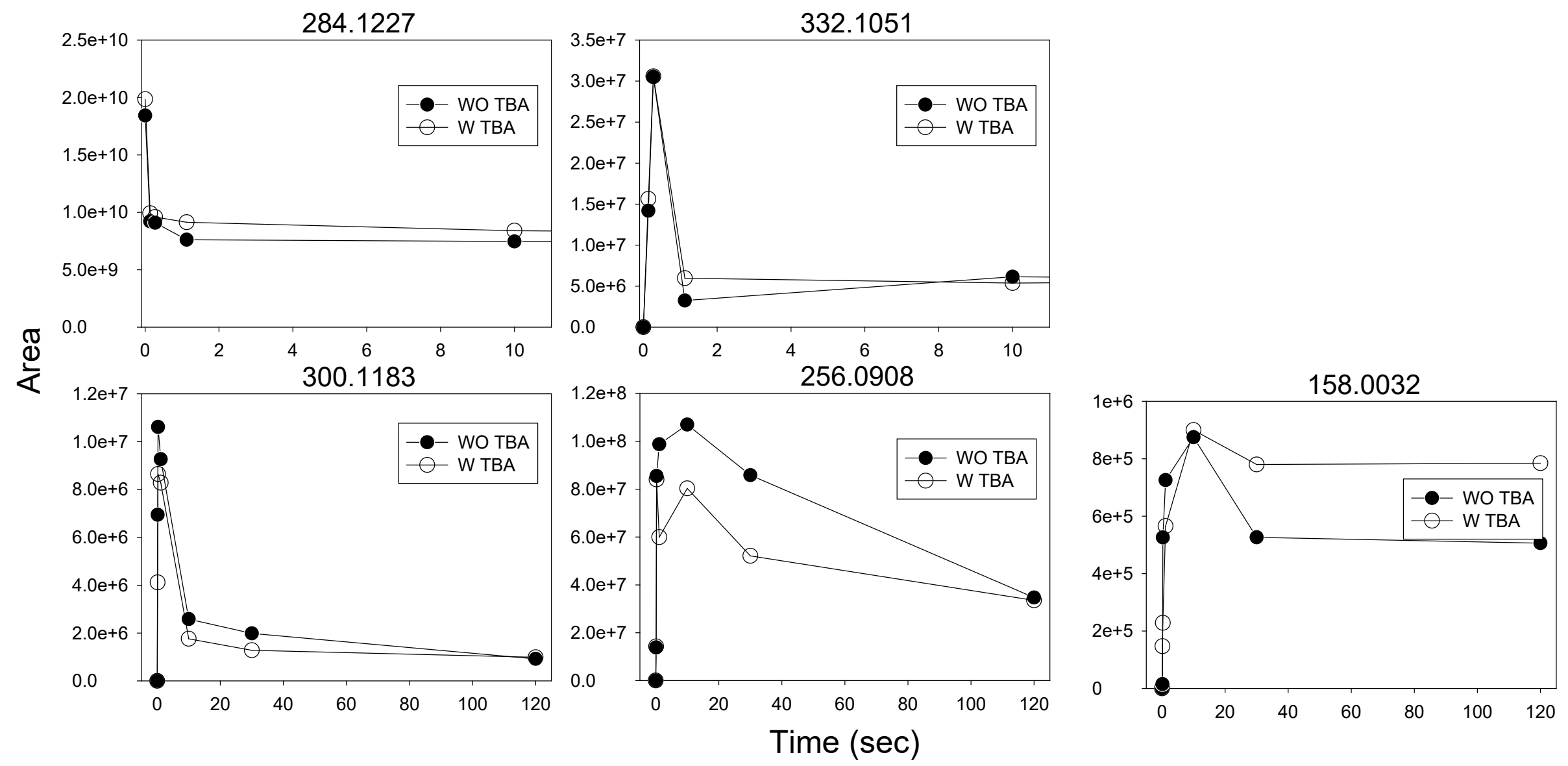

Figure S13. Reaction products of $\mathrm{MB}(\mathrm{m} / \mathrm{z} 284.1227)$ in $\mathrm{Fe}(\mathrm{II}) / \mathrm{PAA}$ process with different reaction times. Reaction condition: $[\mathrm{PAA}]_{0}=100 \mu \mathrm{M}$, $[\mathrm{Fe}(\mathrm{II})]_{0}=100 \mu \mathrm{M},[\mathrm{MB}]_{0}=15 \mu \mathrm{M}$, and if applied $[\mathrm{TBA}]=50,000 \mu \mathrm{M}$. 

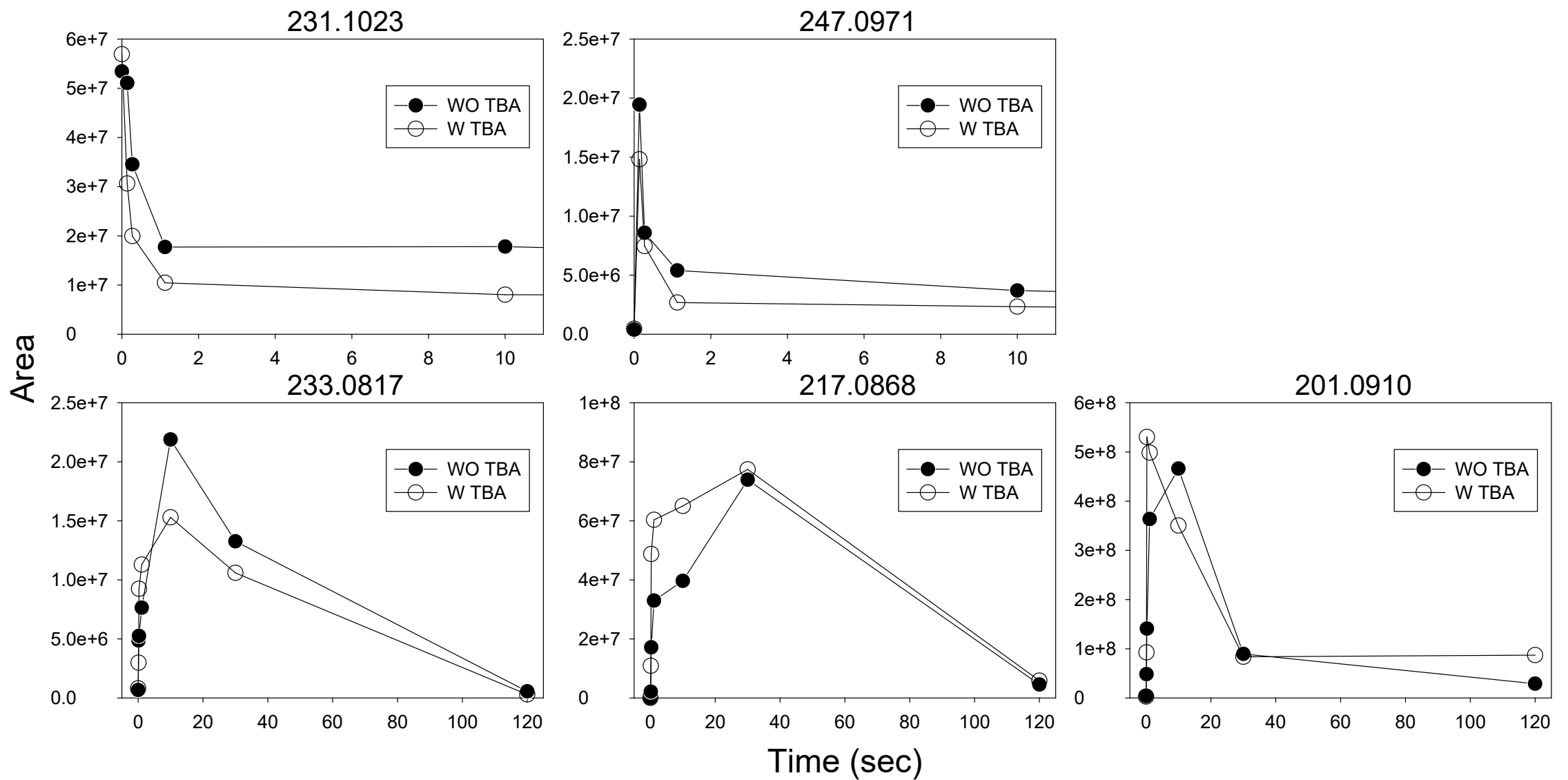

Figure S14. Reaction products of NPX (m/z 231.1023) in "Fe(II)/PAA" process with different reaction times. Experimental condition: $[\mathrm{PAA}]_{0}=$ $100 \mu \mathrm{M},[\mathrm{Fe}(\mathrm{II})]_{0}=100 \mu \mathrm{M},[\mathrm{NPX}]_{0}=15 \mu \mathrm{M}$, and if applied $[\mathrm{TBA}]=50,000 \mu \mathrm{M}$. 

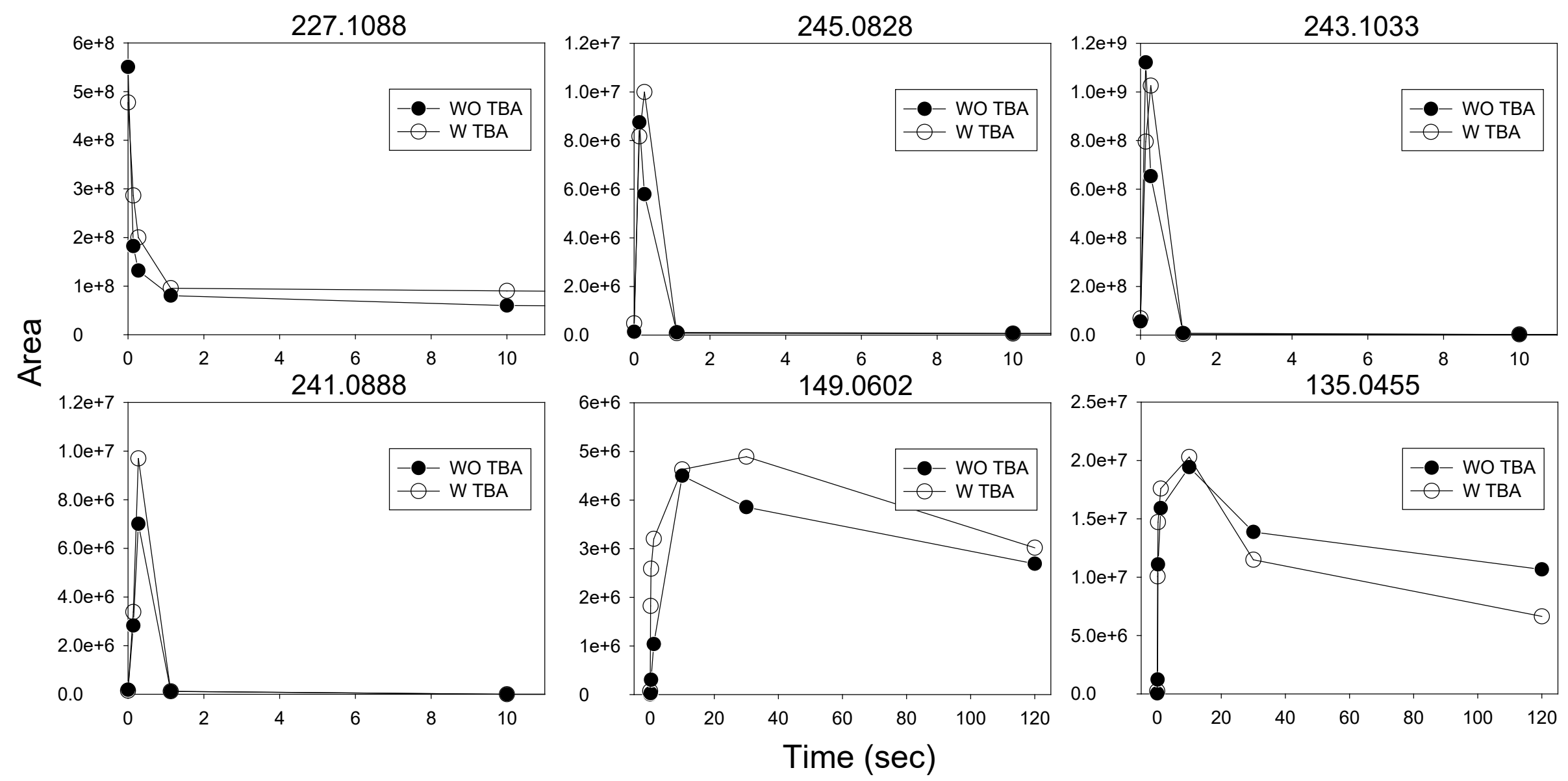

Figure S15. Reaction products of BPA (m/z 227.1088) in "Fe(II)/PAA" process with different reaction times. Experimental condition: $[\mathrm{PAA}]_{0}=$ $100 \mu \mathrm{M},[\mathrm{Fe}(\mathrm{II})]_{0}=100 \mu \mathrm{M},[\mathrm{BPA}]_{0}=15 \mu \mathrm{M}$, and if applied $[\mathrm{TBA}]=50,000 \mu \mathrm{M}$. 


\section{REFERENCES}

(1) Cai, M.; Sun, P.; Zhang, L.; Huang, C. H. UV/Peracetic acid for degradation of pharmaceuticals and reactive species evaluation. Environ. Sci. Technol. 2017, 51 (24), 1421714224.

(2) Vikesland, P. J.; Fiss, E. M.; Wigginton, K. R.; McNeill, K.; Arnold, W. A. Halogenation of bisphenol-A, triclosan, and phenols in chlorinated waters containing iodide. Environ. Sci. Technol. 2013, 47 (13), 6764-6772.

(3) Buffle, M. O.; Schumacher, J.; Salhi, E.; Jekel, M.; von Gunten, U. Measurement of the initial phase of ozone decomposition in water and wastewater by means of a continuous quench-flow system: application to disinfection and pharmaceutical oxidation. Water Res. 2006, $40(9), 1884-1894$.

(4) Viollier, E.; Inglett, P.; Hunter, K.; Roychoudhury, A.; Van Cappellen, P. The ferrozine method revisited: Fe (II)/Fe (III) determination in natural waters. Appl. Geochem. 2000, 15 (6), 785-790.

(5) Gallard, H.; von Gunten, U. Chlorination of phenols: kinetics and formation of chloroform. Environ. Sci. Technol. 2002, 36 (5), 884-890.

(6) Luo, S.; Wei, Z.; Dionysiou, D. D.; Spinney, R.; Hu, W.-P.; Chai, L.; Yang, Z.; Ye, T.; Xiao, R. Mechanistic insight into reactivity of sulfate radical with aromatic contaminants through single-electron transfer pathway. Chem. Eng. J. 2017, 327, 1056-1065.

(7) Schuchmann, M. N.; Von Sonntag, C. The rapid hydration of the acetyl radical. A pulse radiolysis study of acetaldehyde in aqueous solution. J. Am. Chem. Soc. 1988, 110 (17), 56985701.

(8) Bietti, M.; DiLabio, G. A.; Lanzalunga, O.; Salamone, M. Electron transfer properties of alkoxyl radicals. A time-resolved kinetic study of the reactions of the tert-butoxyl, cumyloxyl, and benzyloxyl radicals with alkyl ferrocenes. J. Org. Chem. 2010, 75 (17), 5875-5881.

(9) Darsinou, B.; Frontistis, Z.; Antonopoulou, M.; Konstantinou, I.; Mantzavinos, D. Sonoactivated persulfate oxidation of bisphenol A: kinetics, pathways and the controversial role of temperature. Chem. Eng. J. 2015, 280, 623-633. 
(10) Dulova, N.; Kattel, E.; Trapido, M. Degradation of naproxen by ferrous ion-activated hydrogen peroxide, persulfate and combined hydrogen peroxide/persulfate processes: the effect of citric acid addition. Chem. Eng. J. 2017, 318, 254-263.

(11) Feng, M.; Jinadatha, C.; McDonald, T. J.; Sharma, V. K. Accelerated oxidation of organic contaminants by ferrate (VI): The overlooked role of reducing additives. Environ. Sci. Technol. 2018, 52 (19), 11319-11327.

(12) Vermilyea, A. W.; Voelker, B. M. Photo-Fenton reaction at near neutral pH. Environ. Sci. Technol. 2009, 43 (18), 6927-6933.

(13) Jacobsen, F.; Holcman, J.; Sehested, K. Reactions of the ferryl ion with some compounds found in cloud water. Int. J. Chem. Kinet. 1998, 30 (3), 215-221.

(14) Zhang, C.; Brown, P. J. B.; Hu, Z. Thermodynamic properties of an emerging chemical disinfectant, peracetic acid. Sci. Total Environ. 2018, 621, 948-959.

(15) Luukkonen, T.; Pehkonen, S. O. Peracids in water treatment: A critical review. Crit. Rev. Environ. Sci. Technol. 2017, 47 (1), 1-39.

(16) Panizza, M.; Cerisola, G. Electrochemical generation of $\mathrm{H}_{2} \mathrm{O}_{2}$ in low ionic strength media on gas diffusion cathode fed with air. Electrochim. Acta 2008, 54 (2), 876-878.

(17) Bianchini, R.; Calucci, L.; Lubello, C.; Pinzino, C. Intermediate free radicals in the oxidation of wastewaters. Res. Chem. Intermed. 2002, 28 (2-3), 247-256.

(18) Khursan, S.; Shereshovets, V. AM1 calculations of OH bond dissociation energies in polyoxides. Russ. Chem. Bull. 1996, 45 (2), 312-314.

(19) Ingold, K. U. Peroxy radicals. Acc. Chem. Res. 1969, 2 (1), 1-9.

(20) De Laat, J.; Gallard, H. Catalytic decomposition of hydrogen peroxide by Fe(III) in homogeneous aqueous solution: Mechanism and kinetic modeling. Environ. Sci. Technol. 1999, 33 (16), 2726-2732.

(21) He, J.; Yang, X.; Men, B.; Wang, D. Interfacial mechanisms of heterogeneous Fenton reactions catalyzed by iron-based materials: A review. J. Environ. Sci. 2016, 39, 97-109.

(22) Pignatello, J. J.; Oliveros, E.; MacKay, A. Advanced oxidation processes for organic contaminant destruction based on the Fenton reaction and related chemistry. Crit. Rev. Environ. Sci. Technol. 2006, 36 (1), 1-84. 
(23) De Laat, J.; Gallard, H.; Ancelin, S.; Legube, B. Comparative study of the oxidation of atrazine and acetone by $\mathrm{H}_{2} \mathrm{O}_{2} / \mathrm{UV}, \mathrm{Fe}(\mathrm{III}) / \mathrm{UV}, \mathrm{Fe}$ (III)/ $\mathrm{H}_{2} \mathrm{O}_{2} / \mathrm{UV}$ and $\mathrm{Fe}$ (II) or Fe (III)/ $\mathrm{H}_{2} \mathrm{O}_{2}$. Chemosphere 1999, 39 (15), 2693-2706.

(24) Bokare, A. D.; Choi, W. Review of iron-free Fenton-like systems for activating $\mathrm{H}_{2} \mathrm{O}_{2}$ in advanced oxidation processes. J. Hazard. Mater. 2014, 275, 121-135.

(25) Rokhina, E. V.; Makarova, K.; Lahtinen, M.; Golovina, E. A.; Van As, H.; Virkutyte, J. Ultrasound-assisted $\mathrm{MnO}_{2}$ catalyzed homolysis of peracetic acid for phenol degradation: The assessment of process chemistry and kinetics. Chem. Eng. J. 2013, 221, 476-486.

(26) Rojas, M. R.; Pérez, F.; Whitley, D.; Arnold, R. G.; Sáez, A. E. Modeling of advanced oxidation of trace organic contaminants by hydrogen peroxide photolysis and Fenton's reaction. Ind. Eng. Chem. Res. 2010, 49 (22), 11331-11343.

(27) Mártire, D. O.; Caregnato, P.; Furlong, J.; Allegretti, P.; Gonzalez, M. C. Kinetic study of the reactions of oxoiron (IV) with aromatic substrates in aqueous solutions. Int. J. Chem. Kinet. 2002, 34 (8), 488-494.

(28) Lu, Z.; Continetti, R. E. Dynamics of the acetyloxyl radical studied by dissociative photodetachment of the acetate anion. J. Phys. Chem. A 2004, 108 (45), 9962-9969.

(29) Kamath, D.; Mezyk, S. P.; Minakata, D. elucidating the elementary reaction pathways and kinetics of hydroxyl radical-induced acetone degradation in aqueous phase advanced oxidation processes. Environ. Sci. Technol. 2018, 52 (14), 7763-7774.

(30) Rokhina, E. V.; Makarova, K.; Golovina, E. A.; Van As, H.; Virkutyte, J. Free radical reaction pathway, thermochemistry of peracetic acid homolysis, and its application for phenol degradation: spectroscopic study and quantum chemistry calculations. Environ. Sci. Technol. 2010, 44 (17), 6815-6821.

(31) Chalier, F.; Tordo, P. 5-Diisopropoxyphosphoryl-5-methyl-1-pyrroline N-oxide, DIPPMPO, a crystalline analog of the nitrone DEPMPO: synthesis and spin trapping properties. J. Chem. Soc., Perkin Trans. 2 2002, (12), 2110-2117.

(32) Villamena, F. A.; Hadad, C. M.; Zweier, J. L. Kinetic study and theoretical analysis of hydroxyl radical trapping and spin adduct decay of alkoxycarbonyl and dialkoxyphosphoryl nitrones in aqueous media. J. Phys. Chem. A 2003, 107 (22), 4407-4414. 